KATE HENDERSON

\title{
WHO'S BRINGING UP BABY: DEVELOPING A FRAMEWORK FOR THE TRANSFER OF LEGAL PARENTHOOD IN SURROGACY ARRANGEMENTS
}

\author{
LLM RESEARCH PAPER \\ LAWS 513: LAW AND MEDICINE
}

FACULTY OF LAW

TE WHARE WĀNANGa O TE ÜPOKO O TE IKA A MĀUI

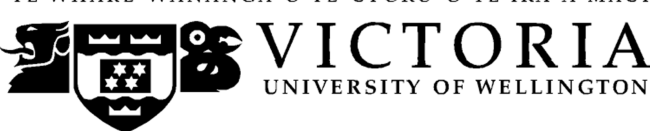

2013 


\section{Abstract}

Surrogacy arrangements defy traditional definitions of parenthood and pose challenges in determining who should be recognised as legal parents. This is exacerbated by the use of assisted reproductive techniques which allow for the separation of genetic, gestational and intentional parenthood, creating questions about the comparative value of these contributions.

This paper identifies that New Zealand legislation dealing with parentage in surrogacy, primarily the Adoption Act 1955 and the Status of Children Act 1969, never contemplated surrogacy arrangements and requires strained interpretation to avoid perverse results. The paper critiques two proposals for reform: the Law Commission's recommendations in the 2005 New Issues in Legal Parenthood Report, and the framework suggested in the Care of Children (Adoption and Surrogacy Law Reform) Amendment Bill.

This paper concludes that the proposed Amendment Bill shows promise, however should incorporate the Law Commission's 2005 recommendations to provide a truly comprehensive framework. This framework should focus on giving effect to the intentions of parties to a surrogacy arrangement, while ensuring the interests of the surrogate are protected and the arrangement is carried out in accordance with recognised ethical principles. It is additionally important that children have an opportunity to know their genetic and/or biological background.

Word Count: The text of this paper (excluding cover page, abstract, table of contents, non-substantive footnotes, appendix and bibliography) comprises approximately 15,149 words.

\section{Subjects and Topics}

Family Law - Legal parenthood

Law and Medicine - Surrogacy

Assisted Reproductive Technology - Regulation 


\section{Contents}

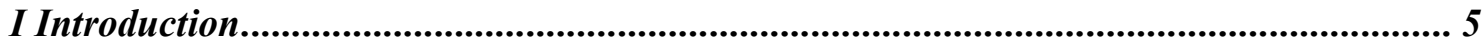

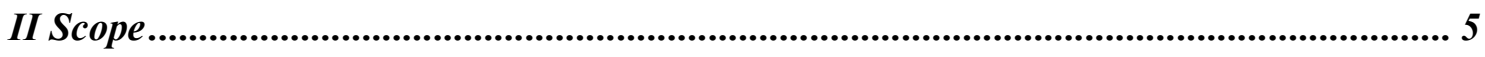

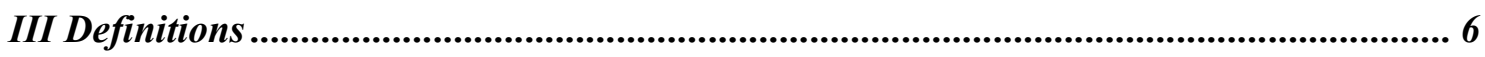

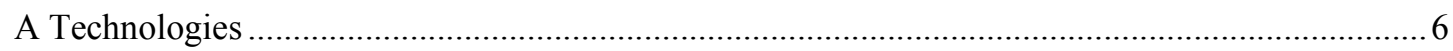

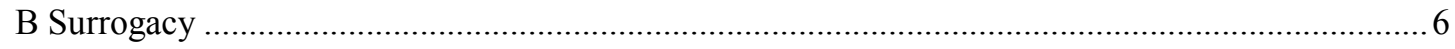

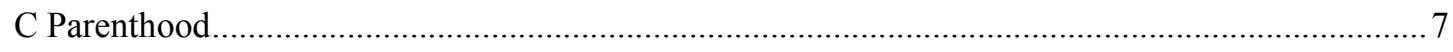

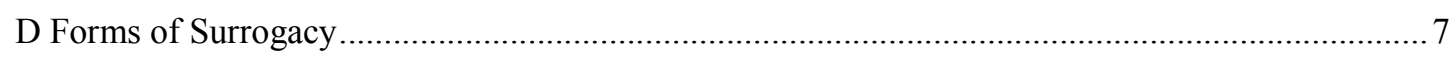

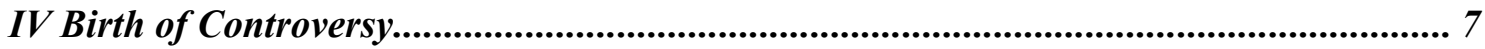

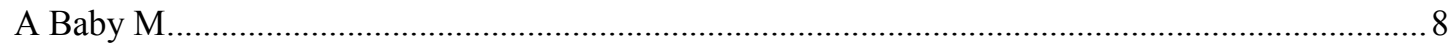

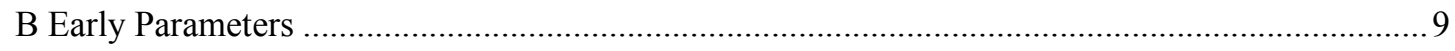

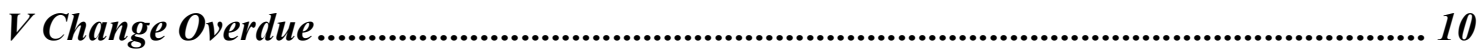

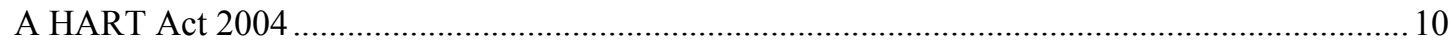

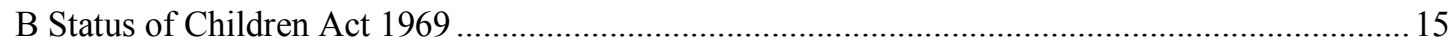

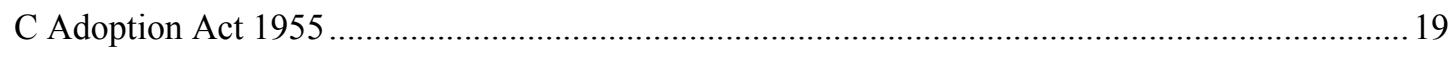

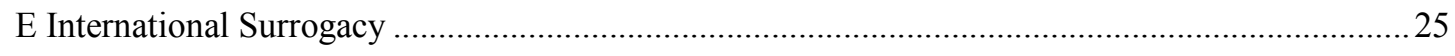

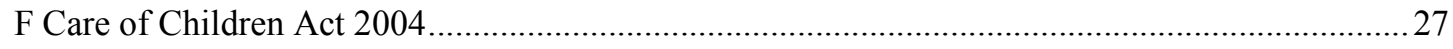

VI Inducing Change: Key Themes......................................................................................... 28

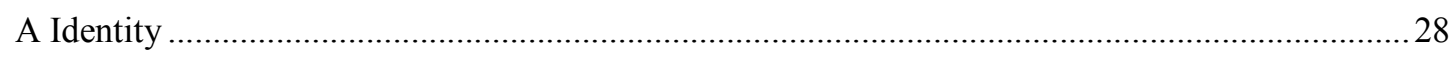

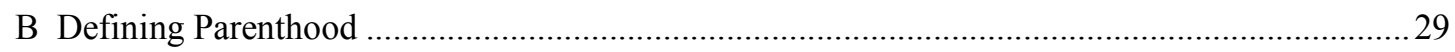

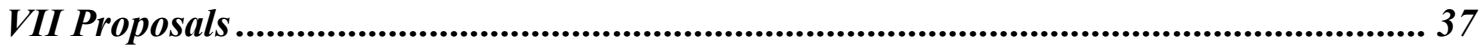

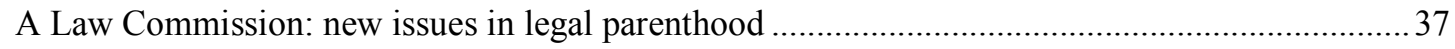

B Care of Children (Adoption and Surrogacy Law Reform) Amendment Bill ................................ 40

VIII Recommendations ................................................................................................................... 46

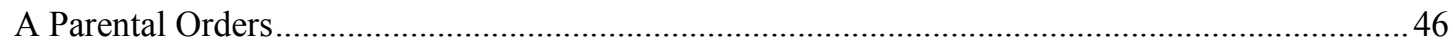

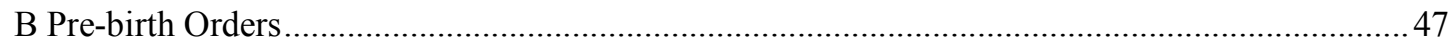

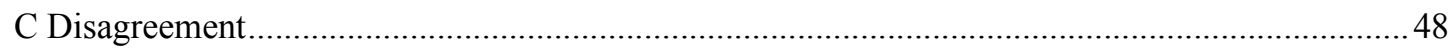




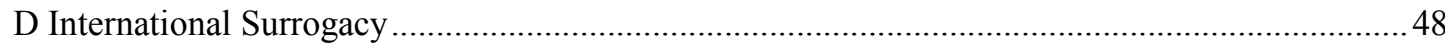

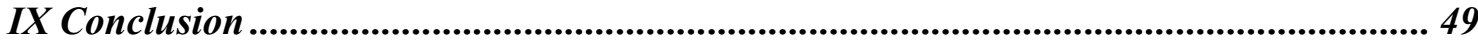

X Appendix 1: Relevant Statutory Provisions.................................................................. 51

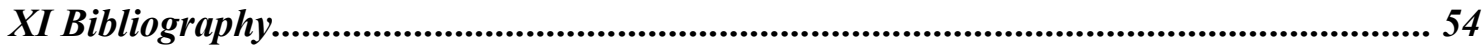




\section{Introduction}

Surrogacy arrangements defy traditional definitions of parenthood and pose challenges in determining who should be recognised as legal parents.

The advent of assisted human reproductive technologies has promoted the practice, and provoked the question of what it means to be a mother by allowing for the separation of genetic and gestational parenthood. In a modern day surrogacy arrangement, a woman may gestate a baby to whom she has no genetic tie, and has no intention to raise.

Yet, the patchwork of legislation in New Zealand governing parentage is still underpinned by two fundamental principles: firstly, that the gestational mother will always be the child's legal mother; and secondly, that if the gestational mother has a partner, that partner is the other legal parent of the resulting child.

To give effect to the intention of parties to a surrogacy agreement, adoption is necessary. The archaic Adoption Act 1955 never contemplated such arrangements, and requires increasingly strained interpretations to avoid perverse results. As a result many social (and often, genetic) parents of children conceived through surrogacy arrangements never legally formalise their role. As posited by Michael Kirby over two decades ago, "the hare of science and technology lurches ahead while the tortoise of the law ambles slowly behind."1

This paper gives a brief introduction to the development of surrogacy in New Zealand, before outlining the current statutes allocating parentage and their awkward application to surrogacy arrangements.

Subsequently, the author identifies and discusses key issues for consideration in developing an appropriate legal framework to determine parentage in surrogacy.

Utilising the conclusions drawn from the latter discussion, the paper critiques two proposals for reform: the Law Commission's recommendations articulated in the 2005 New Issues in Legal Parenthood Report, ${ }^{2}$ and the framework suggested in the Care of Children (Adoption and Surrogacy Law Reform) Amendment Bill.

\section{Scope}

\footnotetext{
${ }^{1}$ Michael Kirby "Medical technology and new frontiers of family law" in Sheila A.M. McLean (ed) Legal Issues in Human Reproduction (Dartmouth Publishing Company Limited, England, 1989) 3 at 14.

${ }^{2}$ Law Commission New Issues in Legal Parenthood (NZLC R88, 2005) [Legal Parenthood Report]
} 
This paper does not comment on the morality of surrogacy. It focuses solely on the law allocating legal parentage when children result from such arrangements. ${ }^{3}$

The Ministerial Committee on Assisted Reproductive Technologies (Ministerial Committee) noted in 1994 that there was considerable literature on the surrogacy debate which their report could not hope to reflect. ${ }^{4}$ That statement is equally true for this paper.

Accordingly this paper focuses on determining the appropriate framework within the New Zealand landscape. While overseas approaches can be instructive, any New Zealand response should be first and foremost "in the light of our own culture and history.",

This framework focuses on transferring legal parenthood where all parties remain in agreement. However, the relevant principles underlying any framework will inform the Court's analysis in approaching determinations of parenthood and day-to-day care should a surrogacy arrangement break down.

\section{Definitions}

The following terms will be used throughout the paper. The definitions are largely drawn from the Law Commission's New Issues in Legal Parenthood Report.

\section{A Technologies}

Assisted Reproductive Technologies (ARTs) are procedures designed to assist an individual or couple to conceive a child with medical assistance. "Procedures may involve the use of donated sperm, eggs, or donated embryo to bring about conception." 6

In vitro fertilisation (IVF) is "[f]ertilisation occurring outside the human body, where eggs are fertilised with sperm in a laboratory, usually in a dish or test tube."7

\section{B Surrogacy}

The Law Commission describes surrogacy as: ${ }^{8}$

$\ldots$ an agreement between a woman and another person or persons, in which she agrees to become pregnant, gestate and give birth to a child and then pass the child to the other person(s) to raise from birth as the child's parents. Surrogacy has developed as a last resort option for women who are infertile.

\footnotetext{
${ }^{3}$ This is consistent with Parliament's approach to legislating on the status of children resulting from donor gamete conception, and the Law Commission's approach in formulating the 2005 Legal Parenthood Report: see (30 June 1987) 482 NZPD 10104; and the Legal Parenthood Report, above $n$ 2, at [2.21].

${ }^{4}$ Ministerial Committee on Assisted Reproductive Technologies Assisted Human Reproduction: Navigating our Future (Reporting to Minister of Justice, July 1994) at 108.

${ }^{5}$ At 26.

${ }^{6}$ Legal Parenthood Report, above n 2, at vii.

${ }^{7}$ At $X$.

${ }^{8}$ At [7.1].
} 
In addition to infertile women, surrogacy is "an avenue whereby men in a gay relationship can have a primary parenting relationship with a child and one of the men can be the genetic father". 9

Surrogacy may be altruistic (unpaid) or commercial (for financial gain). ${ }^{10}$ Commercial surrogacy is illegal in New Zealand (see Part V).

\section{$C$ Parenthood}

Genetic parents are the persons whose eggs or sperm have been used to conceive the child. ${ }^{11}$

Social parents are the persons who take on responsibility for the upbringing of the child. ${ }^{12}$

Intending parents are the persons in a surrogacy arrangement who arrange for the surrogate to gestate and give birth to a child. The intending parents expect to act as the social parents, and may be genetic parents if their gametes were used in conception. ${ }^{13}$

\section{Forms of Surrogacy}

A traditional surrogate is a surrogate mother whose own eggs are used to achieve conception. $^{14}$

This paper defines a surrogate mother who is not genetically related to the child she is carrying for the intending parents as a gestational surrogate. ${ }^{15}$

The paper will also refer to private and clinical surrogacy. Private surrogacy takes place without the use of clinical assistance. For example, the intending father or a donor may provide his semen for use in self-insemination at home. ${ }^{16}$ Conception in private surrogacy can also occur through sexual intercourse. Private surrogacies will always be traditional, as the ovum donation required in gestational surrogacy is a surgical procedure.

Clinical surrogacy occurs through the use of ARTs, including ovum donation. Clinical surrogacy can be traditional or gestational.

\section{Birth of Controversy}

\footnotetext{
${ }^{9}$ At [7.6].

${ }^{10}$ Law Commission New Issues in Legal Parenthood: A discussion paper (NZLC PP54, 2004) at xvii [Legal

Parenthood Discussion Paper]

${ }^{11}$ Legal Parenthood Report, above n 2, at ix.

${ }^{12}$ Legal Parenthood Discussion Paper, above n 10, at $x v$.

${ }^{13}$ Legal Parenthood Report, above n 2, at $x$.

${ }^{14}$ At $x i$.

${ }^{15}$ At $i x$.

${ }^{16}$ At $x i$.
} 
Traditional surrogacy has its origins in antiquity. ${ }^{17}$ In the Bible, Abraham had a child by his servant as his wife was beyond childbearing age. ${ }^{18}$ David Salmon notes: ${ }^{19}$

...the $18^{\text {th }} \mathrm{BC}$ Babylonian legal code of Hammurabi not only recognised the practice of surrogacy and described situations in which it would be permissible, but even laid down guidelines for protection of the rights of both female parties.

Accordingly traditional surrogacy is not a modern phenomenon. However, the development of IVF, egg donation, and embryo donation to treat infertility is. ${ }^{20}$ The first IVF baby, Louise Brown, was born in the United Kingdom in July 1978. ${ }^{21}$ Importantly for the purposes of this paper, the procedure enabled gestational surrogacy: ${ }^{22}$

...[IVF] opened up the possibility that a fertilised embryo could be implanted into the uterus of another woman...[a] woman could, for the first time, gestate and give birth to a child to whom she had no genetic relationship.

ARTs and surrogacy became hot topics in the 1980s. Surrogacy in particular caused what Michael Freeman has described as a "moral panic". ${ }^{23}$ Concerns were born from distaste for the commodification of women and children, and apprehension that "surrogacy had the potential to exploit less economically and occupationally advantaged women by those who did not want to go through the inconvenience of pregnancy." 24

New Zealand's first IVF baby was born in $1984 .{ }^{25}$ No legislation was in place at this time governing ARTs. Government policy had been to hold a "watching brief". ${ }^{26}$

\section{A Baby $M$}

In the 1980s a high profile United States surrogacy case put governments on notice regarding the difficulties that can arise should a surrogate not wish to part with the resulting child. ${ }^{27}$

Dianne Yates MP cited the events outlined in the New Jersey case of In re Baby M (Baby M) as a motivation for the enactment of New Zealand's Status of Children Amendment Act 1987 (see Part V), which related to the legal parentage of children conceived with ARTs. ${ }^{28}$

\footnotetext{
${ }^{17}$ Douglas Cusine "Legal issues in human reproduction" in Sheila A.M. McLean (ed) Legal Issues in Human Reproduction (Dartmouth Publishing Company Limited, England, 1989) 17 at 17.

18 At 17.

${ }^{19}$ David Salmon "In response to a freeman: surrogate motherhood and the feminist perspective" (1995) 1 BFLJ 276 at 276.

${ }^{20}$ At 17.

${ }^{21}$ Susan Donaldson "Test Tube Baby Louise Brown Turns 35" (25 July 2013) ABC News $<$ www.abcnews.go.com>

${ }^{22}$ Legal Parenthood Discussion Paper, above n 10, at [4.8].

${ }^{23}$ Michael Freeman "Is surrogacy exploitative?" in Sheila A.M. McLean (ed) Legal Issues in Human Reproduction (Dartmouth Publishing Company Limited, England, 1989) 164 at 164.

${ }^{24}$ Legal Parenthood Discussion Paper, above n 10, at [4.50].

${ }^{25}$ Ministerial Committee, above n 4, at 1.

${ }^{26}$ Legal Parenthood Discussion Paper, above n 10, at [4.18].

${ }^{27}$ In re Baby M 537 A 2d 1227, (NJ 1988).
} 
In Baby M, Mary Beth Whitehead acted as a traditional surrogate for an intending couple, the Sterns. Pursuant to a surrogacy contract, Mrs Whitehead was inseminated with the intending father's sperm and subsequently conceived and gave birth.

Mrs Whitehead did not wish to surrender the baby, and court proceedings were filed to enforce the contract. The agreement was upheld at first instance but overturned on appeal.

The Appellate Court ruled that the contract was "contrary to public policy" and therefore void and unenforceable. ${ }^{29}$ The Court cited an existing prohibition on payment in consideration of adoption, and the unenforceability of contracts in private placement adoptions. There was no reason why the situation should differ for surrogacy. ${ }^{30}$ In fact, the Court stated that payment of money to a surrogate was likely "illegal, perhaps criminal and potentially degrading to women.",31

The issue was instead treated as a custody dispute to be determined in light of the best interests of the child. The Sterns were given custody on this basis, although Mrs Whitehead remained the natural mother and was awarded visitation rights in recognition of this status. ${ }^{32}$

\section{B Early Parameters}

While the New Zealand legislature declined at this stage to regulate ARTs, the Status of Children Amendment Act 1987 (1987 Act) was passed to provide for the status of children conceived through the use of ARTs. Prior to the enactment of the 1987 Act, motherhood was determined in accordance with the common law presumption of mater semper certa est - the woman who gives birth to the child is the legal mother. ${ }^{33}$ It was presumed that fatherhood was genetic. The man whose sperm brought about the child's conception would be the legal father. ${ }^{34}$

The 1987 Act allowed children conceived within a marriage via donor gametes to be deemed the legal children of their social parents. ${ }^{35}$ Despite assertions that to pass the legislation showed tacit approval of ARTs, others maintained the legislation provided only for the status of the resulting children, and that it allowed Parliament to reserve its approach to ARTs themselves. ${ }^{36}$ The 1987 Act is discussed in depth in Part V.

${ }^{28}$ (23 April 1997) 559 NZPD 1227.

${ }^{29}$ In re Baby $M$, above $\mathrm{n} 27$, at 411, 422.

${ }^{30}$ At 422 .

${ }^{31}$ At 411 .

${ }^{32}$ At 411 .

${ }^{33}$ The Ampthill Peerage [1977] AC 547 at 577 (HL) as cited in Legal Parenthood Discussion Paper, above n 10, at [2.1].

${ }_{35}$ Legal Parenthood Discussion Paper, above n 10, at [2.1].

${ }^{35}$ See Part 2, Status of Children Act 1969.

${ }^{36}$ (2 April 1987) 479 NZPD 8271, 8273. 
The 1987 Act proactively contemplated the practice of egg donation, ${ }^{37}$ which became available in New Zealand from 1992. ${ }^{38}$ Accordingly, gestational surrogacy became possible.

\section{INECART}

In 1993, the Government established an Interim National Ethics Committee on Assisted Reproductive Technologies (INECART). ${ }^{39}$ ART service providers would submit protocols for the ethics body for a decision on whether they were appropriate. ${ }^{40}$ In 1994, INECART declined an application for IVF altruistic surrogacy. ${ }^{41}$ This decision was criticised by the Ministerial Committee, ${ }^{42}$ the first non-government inquiry into ART in New Zealand. ${ }^{43}$

\section{NECAHR}

In 1995, INECART was replaced by the National Ethics Committee on Assisted Human Reproduction (NECAHR). NECAHR gave ethics approval for ART procedures on a case-bycase basis. $^{44}$

In 1997, ethical approval for altruistic IVF surrogacy was given. Draft guidelines were issued indicating when NECAHR would be prepared to approve applications. ${ }^{45}$ NECAHR never authorised a commercial surrogacy arrangement. ${ }^{46}$

\section{$V$ Change Overdue}

This section will provide an in-depth look at the legislation currently in force impacting upon surrogacy arrangements. This includes both the legislation governing the practice itself, and that which defines the legal parent-child relationship.

\section{A HART Act 2004}

The Human Assisted Reproductive Technology Act 2004 (HART Act) was an amalgamation of two substantively similar ART bills - the Human Assisted Reproductive Technology Bill, introduced by Dianne Yates MP in 1996, and the Assisted Human Reproduction Bill, introduced by the government in 1998. An extensive supplementary order paper introduced in

\footnotetext{
37 (30 June 1987) 482 NZPD 10104.

${ }^{38}$ Legal Parenthood Discussion Paper, above n 10, at [3.4].

39 At [4.19].

${ }^{40}$ Ministerial Committee, above $\mathrm{n} 4$, at 3.

${ }^{41}$ Mark Henaghan and Bill Atkin, Family Law Policy in New Zealand (4 ${ }^{\text {th }}$ ed, Lexis Nexis, Wellington, 2013) at 278.

${ }^{42}$ Legal Parenthood Discussion Paper, above n 10, at [4.19]

${ }^{43}$ Henaghan and Atkin, Family Law Policy, above n 41, at 255-256.

${ }^{4}$ At [4.20]

${ }^{45}$ At $[4.20]$

${ }^{46}$ Human Assisted Reproductive Technology Bill (2004) (195-2) (select committee report) at 12.
} 
April 2003 by David Benson-Pope MP also constituted a central element of the eventual Act's design. ${ }^{47}$

The Act sets up a three tiered model of regulation for ARTs. ${ }^{48}$ The first tier entirely prohibits a number of controversial procedures, for example human cloning. ${ }^{49}$

The remaining tiers required the creation of an Advisory Committee on Assisted Reproductive Technologies (ACART), ${ }^{50}$ and an Ethics Committee on Assisted Reproductive Technologies (ECART). ${ }^{51}$

ACART has the power to declare particular ART procedures established procedures. ${ }^{52}$ These second tier procedures may be undertaken by fertility clinics without case-by-case ethical approval. Current established procedures include most instances of gamete donation, and IVF.

A third tier of non-established procedures must be considered by ECART on a case by case basis. $^{53}$ ACART issues guidelines and provides advice to ECART on these procedures. ECART subsequently determines and monitors applications for ARTs in accordance with these guidelines. ${ }^{54}$ Surrogacy arrangements fall within this third tier. ${ }^{55}$

\section{Relevant provisions}

(a) Section 4: principles

These principles guide all persons exercising powers or performing functions under the HART Act, including ACART and ECART. ${ }^{56}$

Principle (a) states that: ${ }^{57}$

The health and well-being of children born as a result of the performance of an assisted reproductive procedure or an established procedure should be an important consideration in all decisions about that procedure.

47 At 1 .

${ }^{48}$ Dr Lynley Anderson, Jeanne Snelling and Huia Tomlins-Jahnke "The practice of surrogacy in New Zealand" (2012) 52 Aust N Z J Obstet Gynaecol 253 at 253. This model has additionally been referred to as "four tiered". The fourth tier consists of a provision allowing a moratorium to be imposed on a procedure for up to 18 months to allow time for the development of guidelines: Henaghan and Atkin, Family Law Policy, above n 41, at 258259.

${ }^{49}$ See Part 2, Human Assisted Reproductive Technology Act 2004: Prohibited and regulated activities.

${ }^{50}$ Human Assisted Reproductive Technology Act 2004, s 32.

${ }^{51}$ Section 27.

52 Section 6; Henaghan and Atkin, Family Law Policy, above n 41, at 258.

53 At 258; Human Assisted Reproductive Technology Act 2004, s 28.

${ }^{54}$ Human Assisted Reproductive Technology Act 2004, s 35.

${ }^{55}$ Henaghan and Atkin, Family Law Policy, above n 41, at 258.

${ }^{56}$ Human Assisted Reproductive Technology Act 2004, s 4; ACART Guidelines on Surrogacy Arrangements involving Providers of Fertility Services (Guidelines issued to ECART under section 35 of the Human Assisted Reproductive Technology Act 2004, November 2008) at 2.

${ }^{57}$ Human Assisted Reproductive Technology Act 2004, s 4(a). 
The above wording is in contrast to the majority of family law legislation dealing with child welfare, in which the child's best interests as paramount. ${ }^{58}$ The language of paramountcy was originally used, but diluted throughout the legislative process. ${ }^{59}$

This was in part because ARTs were considered to be inherently riskier than natural conception. Parliament was wary that this inherent risk could be used to veto any prospective ART procedure. ${ }^{60}$

Additionally, paramountcy was avoided as requiring a child's best interests to be treated as superior to all others could prevent the appropriate balancing of other significant factors. In relation to surrogacy for example, it will be important to ensure the surrogate is protected. ${ }^{61}$

On that note; principle (c) finds: ${ }^{62}$

... [that] women, more than men, are directly and significantly affected by [the application of ARTs], and the health and wellbeing of women must be protected in the use of these procedures.

Principle (e) holds that "donor offspring should be made aware of their genetic origins and be able to access information about these origins." 63

This principle reflects the obligations committed to by New Zealand under the United Nations Convention on the Rights of the Child (UNCROC), notably: a child's right from birth to know their parents; the right to preserve their identity; and the right to seek and receive information of all kinds. ${ }^{64}$

The Act accordingly sets up a comprehensive registry whereby children resulting from donor gamete conception can locate genetic and identifying information about their donor parents. ${ }^{65}$

Inevitably clinical surrogacy will involve gamete donation. Usually access to genetic information in clinical donor gamete conception is necessary as the resulting child will not have been raised by the genetic donor parent. Surrogacy is unique in that it is possible that the social parents of the child are also both genetic parents, but the child does not know the gestational parent. There is no registry for surrogate mothers. For further discussion of identity in surrogacy, see Part VI.

\footnotetext{
${ }^{58}$ See the Care of Children Act 2004, s 4; Children, Young Persons and Their Families Act 1989, s 6.

${ }^{59}$ Bill Atkin "Regulation of Assisted Human Reproduction: The Recent New Zealand Model in Comparison with Other Systems" (2005) 11 RJP/NZACL 81 at 85.

${ }^{60}$ Human Assisted Reproductive Technology Bill (195-2) (select committee report) at 5.

${ }^{61}$ Legal Parenthood Report, above n 2, at [1.19].

${ }^{62}$ Human Assisted Reproductive Technology Act 2004, s 4(c).

${ }^{63} \mathrm{~S} 4(\mathrm{e})$.

${ }^{64}$ United Nations Convention on the Rights of the Child 1577 UNTS 3 (opened for signature 20 November 1989, entered into force 2 September 1990), arts 7.1, 8.1, 13.1, as cited in Legal Parenthood Discussion Paper, above $\mathrm{n} 10$, at [5.13]

${ }^{65}$ Human Assisted Reproductive Technology Act 2004, Part 3.
} 
Principle (f) provides that "the needs, values and beliefs of Maori should be considered and treated with respect". 66

This principle played a significant part in developing the "ethos of openness" in regards to genetic information promoted by the Act; ${ }^{67}$ as knowledge of genealogical origins is of particular importance in tikanga Maori. ${ }^{68}$

\section{(b) Section 14}

Section 14 provides that although a surrogacy arrangement is not of itself illegal, it cannot be enforceable against any person.

Section 14(3) prohibits commercial surrogacy arrangements; holding that it will be an offence to give or receive valuable consideration in exchange for participation in a surrogacy arrangement.

Section 14(3) does not apply to payments to fertility providers for reasonable and necessary expenses, for example medical or legal expenses incurred. ${ }^{69}$

\section{ACART guidelines and practice}

(a) Guidelines

Clinical surrogacy is considered a non-established procedure, and requires ethical review. Private surrogacy will not be directed through a clinic, and therefore will not be subject to the ECART process. ${ }^{70}$

ECART must review each case in accordance with the ACART Guidelines on Surrogacy Arrangements involving Providers of Fertility Services. The guidelines require that ECART, in considering applications, be guided by the principles of the HART Act $2004 .^{71}$

Principal requirements include that at least one of the intending parents will be a genetic parent of any resulting child, and that the intending mother has a medical condition preventing pregnancy or causing pregnancy to be potentially harmful, or a medical diagnosis of unexplained infertility that has not responded to other treatments. ${ }^{72}$

\footnotetext{
${ }^{66}$ Human Assisted Reproductive Technology Act, s 4(f).

${ }^{67}$ (6 October 2004) 620 NZPD 15900.

${ }^{68}$ Legal Parenthood Discussion Paper, above n 10, at [1.11]

${ }^{69}$ Human Assisted Reproductive Technology Act, s 14(3).

${ }^{70}$ Henaghan and Atkin, Family Law Policy, above n 41, at 277.

${ }^{71}$ ACART Guidelines, above n 56, at 2.

72 There is very little research available on what might constitute a "medical condition": Dr Lynley Anderson and Professor Mark Henaghan "Surrogacy and s2(a)(ii): Interpreting the "medical condition" requirement in ACART's Guidelines on Surrogacy Arrangements involving Providers of Fertility Services: How "Medical" is "Medical"?: The ethical and legal implications of the "medical condition" requirement in an intending mother's application of surrogacy" (2012) 7 NZFLJ 130 at 130.
} 
The guidelines require that discussions about the intended day-to-day care, guardianship, or adoption of a resulting child have occurred. Independent medical and legal advice is required, as well as counselling for all parties involved. ${ }^{73}$

The relevant factors to be taken into account by ECART in each case include whether the intending surrogate has completed her family; whether the relationship between the surrogate and the intending parents safeguards the wellbeing of all parties, especially any resulting child; whether legal reports indicate the parties clearly understand the legal issues involved; the value of any counselling that has occurred, as well as the on-going availability of counselling; and whether the residency of the parties safeguards the wellbeing of all parties, especially any resulting child. ${ }^{74}$

(b) Social infertility

The guidelines focus on medical diagnoses, and exclude social infertility. ${ }^{75}$ Social infertility encompasses those who have no medical impediment, but are unable to have children for social reasons - for example a single person, or a same-sex couple. ${ }^{76}$

Women who are socially infertile can normally achieve the desired outcome with gamete donation. However gamete donation cannot provide a solution for homosexual and single males who wish to have a genetically related child. These men will not meet ACART's current criteria. The infertility requirement cannot be stretched so far as to suggest that being male is a medical condition. ${ }^{77}$

ACART have agreed that this provision constitutes unjustified discrimination, and that the medical criteria must change. ${ }^{78}$ Consultation began on this point in $2012,{ }^{79}$ and accordingly the author presumes that single and homosexual males will be eligible for ECART approval in the near future. Therefore when considering the appropriate framework for parentage, it is important to include mechanisms for the transferral of parentage to male intending couples (and singles). This is exacerbated by evidence male couples are resorting to international surrogacy to attain genetic children, and seeking to have their parenthood recognised under New Zealand law upon their return. ${ }^{80}$

(c) Practice

\footnotetext{
${ }^{73}$ ACART Guidelines, above n 56, at 3.

${ }^{74}$ At 3 .

75 Anderson and Henaghan, "Surrogacy and s 2(a)(ii)", above n 72, at 130.

${ }^{76}$ Henaghan and Atkin, Family Law Policy, above n 41, at 252.

${ }^{77}$ Debbie Dunbar "Surrogacy for same sex male couples" (21 March 2013) Rainey Collins Lawyers $<$ www.raineycollins.co.nz $>$

${ }^{78}$ Advisory Committee on Assisted Reproductive Technology: Annual Report 2011/2012 (ACART, November 2012) at 4.

${ }^{79}$ At 4.

${ }^{80}$ See: Re an application by BWS to adopt a child [2011] NZFLR 621; Rachel Morton "Couple's kids denied citizenship over surrogacy" (15 September 2013) 3 News <www.3news.co.nz>
} 
The ACART guidelines are robust requirements, yet practice shows that most applications are approved. ${ }^{81}$ Between 2004 and 2011, NECAHR and ECART received 111 surrogacy applications, 102 of which were approved. ${ }^{82}$

\section{B Status of Children Act 1969}

The Status of Children Act 1969 governs legal parenthood in New Zealand. Originally enacted to dispose of the concept of "illegitimacy" for children born outside a marriage, ${ }^{83}$ the Act was amended in 1987 to remove uncertainty about the status of children conceived through ARTs. The Status of Children Amendment Act 2004 (2004 Act) replaced the 1987 Act, continuing the effect of the latter Act while introducing a small number of amendments. $^{84}$

\section{Legal parenthood}

Legal parenthood, among other things, determines a child's citizenship, inheritance rights, and provides rights to child support should parental relationships break down. ${ }^{85}$ Typically parenthood will entail the automatic bestowal of guardianship. ${ }^{86}$

Guardianship will usually enable the exercise of day-to-day care of the child, in addition to the ability to make decisions about important matters such as healthcare or schooling. ${ }^{87}$

\section{Natural conception}

Historically, parenthood has been grounded in genetic connection. Absent genetic connection, hopeful parents to be are screened by the state to determine their suitability. ${ }^{88}$

When children are conceived naturally, maternity can be conclusively demonstrated with evidence of birth giving. ${ }^{89}$ However, prior to advances in modern technology it was difficult to determine genetic fatherhood. "A presumption exists where conclusive proof is not readily available". ${ }^{90}$ Accordingly, a child born to a woman during her marriage was presumed to be

\footnotetext{
${ }^{81}$ Dr Lynley Anderson “The practice of surrogacy”, above n 48, at 253.

${ }^{82}$ Henaghan and Atkin, Family Law Policy, above n 41, at 279.

${ }^{83}$ Legal Parenthood Discussion Paper, above n 10, at [5.12]

${ }^{84}$ In relation to ART, the 2004 Act replaced the term "married" with the new societal norm "partnered", which significantly, is gender neutral and would allow a female non-donor partner to be deemed the legal parent. Additionally the Act directed that non-partner donors would never be considered for any purposes the parent of any child resulting from the pregnancy, abolishing the notion that if a single or lesbian woman conceived as a result of sperm donation, the donor would be a "shell father" - recognised on the birth certificate, but without any rights or liabilities in relation to the child. See Henaghan and Atkin, Family Law Policy, above n 41, at 47; and Status of Children Amendment Act 2004.

${ }^{85}$ Legal Parenthood Report, above $n$ 2, at [1.2].

${ }^{86}$ At [1.1].

${ }^{87}$ At [1.2].

${ }^{88}$ At [3.18].

${ }^{89}$ At [4.49].

${ }^{90}$ At [4.49].
} 
the genetic child of her husband. ${ }^{91}$ Prior to 1969 this presumption also ensured that children within a marriage did not suffer the adverse legal consequences of illegitimacy. ${ }^{92}$

Although it has become easier to determine genetic fatherhood, it is impractical to expect genetic testing be undertaken in every instance. Often the father can be easily ascertained due to a relationship with the mother of the child. Therefore the paternity presumption is retained in s 5 of the Status of Children Act, providing that a child born to a woman during her marriage, shall in the absence of evidence to the contrary, be presumed to be the child of the mother and her husband.

If the parents of a child are not married, the most typical means of recognising paternity in law is a joint acknowledgement of paternity. ${ }^{93}$ Acknowledgement can occur through joint signatures on an instrument executed as a deed, or naming the father on the birth certificate. ${ }^{94}$

\section{Parenthood and ART}

"Prior to the 1987 Amendment Act... a gamete donor was still, in law, a parent to the child with full legal liabilities and rights." 95 This affected not only the "integrity of the [recipient] family unit" but also the donors, who did not intend to assume parental liabilities. ${ }^{96}$ One adverse result was that donors were less open about their identity due to fear of incurring liability for the child. ${ }^{97}$

The 1987 Act's (and subsequently, the 2004 Act's) philosophy was that parentage "should be decided on a social rather than a biological basis." 98 This recognised that gamete donors generally "do not want the rights, duties and liabilities of parenthood, whereas the recipients of donation do." 99

Accordingly, the Status of Children Act provides that where ARTs are used parental status is transferred from the donor to the mother and her partner automatically. Donors lose any rights and responsibilities towards the child. ${ }^{100}$ This includes scenarios in which single women are the recipients of sperm donation. ${ }^{101}$

The status of children conceived as a result of ART procedures is set out in Part 2 of the Act.

\section{(a) Maternity}

\footnotetext{
91 At [4.7].

92 At [4.7].

${ }^{93}$ At [4.5].

${ }^{94}$ At [4.5]; Status of Children Act 1969, s 8.

${ }^{95}$ At $[6.4]$.

${ }^{96}$ At $[6.5]$.

${ }^{97}$ At $[6.5]$.

${ }^{98}$ Henaghan and Atkin, Family Law Policy, above n 41, at 270.

${ }^{99}$ At 47; Legal Parenthood Report, above n 2, at [6.14].

${ }^{100}$ Legal Parenthood Discussion Paper, above n 10, at xix.

${ }^{101}$ See Henaghan and Atkin, Family Law Policy, above n 41, at 47.
} 
If a woman conceives with donor gametes, she is for all purposes the mother of the child. ${ }^{102}$

(b) Consenting partner

Section 18 determines that, if the woman who falls pregnant as a result of an ART procedure has a non-donor partner who has consented to the procedure, that partner is for all purposes the parent of the child and the donor is deemed not to be a parent.

Section 26 deals with scenarios of conflicting evidence of paternity, holding that the sections which relieve the genetic donors of their legal rights and liabilities in relation to the child will trump any conflicting evidence that the man who produced the semen was the father of the child of the pregnancy.

\section{Identity}

While the above provisions provide the social parent with automatic status in relation to the child, they create a legal fiction in that the recipient parents are held out in law to be the child's genetic parents. ${ }^{103}$

Unlike adoption, in which the genetic parents are initially named but then removed, genetic donors are never named on the birth certificate. Instead, the HART Act 2004 requires that information about the donor is included in a donor registry. Access by the resulting child to the donor registry and accordingly, information about the donor relies on the parents informing the child about the circumstances of their conception. ${ }^{104}$

\section{Application to surrogacy}

The Act itself does not specifically provide for surrogacy. ${ }^{105}$

Sir Geoffrey Palmer (then Minister of Justice) supposedly promoted the 1987 Act in part to prevent a Baby $M$ case in New Zealand, by establishing the rights of a legal birth mother. ${ }^{106}$ If this is accepted, it can be inferred from the inclusion of the maternity rule that Parliament intended the gestational mother to be the legal mother of any child born pursuant to a surrogacy arrangement.

Regardless, as generally surrogacy will involve the use of ARTs, surrogacy arrangements will come under the deeming rules applicable to donor gamete conception. The exception is a traditional surrogacy arrangement achieved by sexual intercourse, which does not require ARTs and accordingly would not fall under Part 2 of the Act.

\footnotetext{
102 Status of Children Act 1969, s 17.

${ }^{103}$ Legal Parenthood Discussion Paper, above n 10, at xix.

104 At [3.41].

105 (30 June 1987) 482 NZPD 10108

106 (23 April 1997) 559 NZPD 1227.
} 
Where ARTs are utilised, the rules designed for gamete donation produce consequences almost exactly opposite to the intent of parties to a surrogacy arrangement. ${ }^{107}$

The surrogate is the legal mother of any resulting child. This position is unchanged even if she is a gestational surrogate who conceived with the ovum of the intending mother or an egg donor. The surrogate subsequently bears all the legal rights and liabilities of motherhood "unless and until the child becomes adopted." 108

(a) Psychological commitment

Part 2 of the Status of Children Act intends for parenthood to be based on "the psychological commitment of the social parents rather than on a biological blood-line", ${ }^{109}$ but fails to do so in regard to surrogacy arrangements.

The preference to vest legal motherhood in the gestational parent can be attributed to a desire to protect the interests of the surrogate. The New Zealand legislature has consistently expressed concern about the relationship between surrogacy arrangements and the exploitation of women, recognising the emotional difficulty in requiring that a child which has been gestated for nine months be relinquished. ${ }^{110}$

This provision is consistent with the policy not to allow the enforceability of a surrogacy arrangement by the courts, signalling Parliament was not prepared to allow the transfer of parental status through contractual agreement.

While a mechanism to protect the autonomy of the surrogate is important, the current status quo of determining the surrogate the legal mother until and if an adoption is carried out may negate the intention of the surrogate herself. Similarly to gamete donors, a surrogate generally has no desire to raise the child and accordingly no wish to attract rights and responsibilities to the child. Allowing a mechanism whereby the surrogate, who never intended to parent the child, could easily divest herself of legal parenthood in favour of the intending parents could in fact promote her autonomy.

(b) Surrogate's partner and legal parenthood

If the surrogate's partner has approved of and agreed to the process, they will be deemed the additional legal parent under section 18. The deeming provision will prevail despite any contradictory evidence that an intending parent has a genetic link to the child. ${ }^{111}$

\footnotetext{
${ }^{107}$ Family Law Service (online looseleaf ed, LexisNexis) at [10.3]

108 At [10.3]

109 At [10.2]

${ }^{110}$ See Legal Parenthood Preliminary Report, above n 10, at [4.50]; (23 April 1997) 559 NZPD 1228 -1231; (17

November 1998) 573 NZPD 13229

${ }^{111}$ Status of Children Act 1969, s 26.
} 
In Re Application by $A L H$, the intending couple in a surrogacy arrangement applied for an adoption order. ${ }^{112}$ The child in question was conceived in a private, traditional surrogacy arrangement in which the intending father had provided his sperm with which the surrogate was inseminated. The surrogate's husband gave his blessing to the arrangement. This consent saw him deemed the child's legal father by section 18 .

Nonetheless, the surrogate placed her own name and that of the intending, genetic father on the child's birth certificate. The Family Court ordered that the intending father could not appear on the certificate until an adoption order was made. The case clarified that the intending father could not be the father in law, as: ${ }^{13}$

...a presumption can only be displaced where the surrogate's husband is presumed to be the legal father (as under s 5). Where the surrogate's husband is deemed to be the father under Part 2 of the Act...the intending father needs to adopt the child to become a legal parent. Section 26 makes it clear that the provision in $\mathrm{s} 18$, not s 5 , has overriding effect.

A prospective intending father noted on his blog that he considered the overriding deeming provision to be a significant downside of the current regime: ${ }^{114}$

Our [surrogate] was married, so, for the purposes of a birth certificate, the law would only recognise her husband as the legal father of my child. If I had wanted to become legally recognised as the father of this child...I would have had to go through an adoption process with my wife. To me this was a level of complexity and legal nonsense that I just could not get my head around.

\section{Adoption Act 1955}

\section{Features}

The Adoption Act 1955 operates as a statutory guillotine, ${ }^{115}$ removing the birth parent's legal status (and consequently all responsibility for the child's upbringing) and deeming substitute parents to be the child's legal parents. ${ }^{116}$ The consent of the birth mother must be obtained, absent abandonment or neglect. ${ }^{117}$ In New Zealand, a birth mother is not legally able to give consent until at least 10 days after the birth of the child. ${ }^{118}$

Prospective adoptive parents are vetted by Child, Youth and Family (CYFS). An order may only be made if the court is satisfied that the adoptive parents are fit and proper persons to

\footnotetext{
${ }^{112}$ Re Application by ALH FC North Shore FAM-2011-044-371, 11 August 2011.

113 At [16].

114 "What about me or is that far too selfish?" (27 May 2010) How Green is My Grass? <www.djpnz.com>

${ }^{115}$ Law Commission Adoption and Its Alternatives: A Different Approach and a New Framework (NZLC R65, 2004) at [29].

${ }^{116}$ Legal Parenthood Discussion Paper, above n 10, at [1.3]

${ }^{117}$ Adoption Act 1955, ss $7-8$

${ }^{118}$ Law Commission Adoption, above n 115, at [36]; Adoption Act 1955, s 7(7)
} 
raise the child and that the welfare and interests of the child will be promoted by the adoption. $^{119}$

The Adoption Act only permits single persons, and spouses jointly, to adopt. ${ }^{120}$

Adoption transfers legal parenthood in two stages: ${ }^{121}$

...custody can be transferred in an interim order made by the court...and six months after the interim order is granted, the prospective parents may then apply to the court for a final adoption order.

While this is the usual position, the court has previously been inclined to issue a final adoption order immediately where the adopting parents were the full genetic parents of the child born to a surrogate. ${ }^{122}$

Upon adoption, the child's birth certificate is altered by removing any reference to the birth parents, and listing the adoptive parents as the child's genetic and legal parents, suppressing the facts of their relationship and creating a legal fiction. ${ }^{123}$

\section{Critique}

The requirement that the surrogate will be the legal mother (and that any existing partner will be deemed a legal parent) until adoption occurs is onerous given the widespread criticism of the Adoption Act and its awkward application to surrogacy arrangements.

Professor Mark Henaghan has stated that "The Adoption Act...was passed at a time when some Family Court Judges were not even twinkles in their parents' eyes and the others were running around in nappies." ${ }^{~} 24$ Rampant social changes have since occurred. For example, the Act only provides for single persons or spouses to adopt, despite the prevalence of de facto relationships in modern society.

(a) Purpose

Adoption was originally developed to deal with scenarios where children could not be looked after by their genetic parents. ${ }^{125}$

The Law Commission detailed in its 2000 report Adoption and its Alternatives that adoption has moved on, and now serves a variety of purposes beyond providing substitute parents

\footnotetext{
${ }^{119}$ Section 11

${ }^{120}$ Section 3

${ }^{121}$ Legal Parenthood Report, above n 2, at [7.24]

${ }^{122}$ See Re Adoption of H FC Wanganui FAM-2003-034-17, 13 August 2003 as cited in Legal Parenthood Discussion Paper, above n 10, at [4.44]

${ }^{123}$ Legal Parenthood Discussion Paper, above n 10, at [1.3]; Law Commission Adoption, above n 115, at [29].

${ }^{124}$ Mark Henaghan "Editorial: Adoption - time for changes" (2006) 5 NZFLJ 131 at 131.

${ }^{125}$ Legal Parenthood Discussion Paper, above n 10, at [1.3]
} 
when genetic parents are unwilling or unable to raise a child. ${ }^{126}$ Judge von Dadelszen elaborated on this point in relation to surrogacy in 2011 case $I A M:^{127}$

...the Act needs to be interpreted in the light of the social climate and society's expectations in the second decade of the $21^{\text {st }}$ century...[otherwise] no adoption would be granted where surrogacy, for example, led to birth and subsequent application.

(b) Closed adoptions

In 1955, children born outside of wedlock suffered negative legal and social consequences. Once adopted into a marriage their genetic heritage was suppressed and it was presupposed that their genetic parents would not be known to them. ${ }^{128}$

This culture of secrecy was discovered to have negative consequences for adopted children, who had no way of knowing their genetic origins. ${ }^{129}$ Public consciousness of this harm led to a dramatic change in adoption practice. ${ }^{130}$ Children are now more likely to be adopted openly. ${ }^{131}$ In 1985, the Adult Adoption Information Act was enacted and provides a process whereby birth parents and adopted children could locate one another. ${ }^{132}$

This change in practice has never been given effect in the Adoption Act. ${ }^{133}$ The statutory guillotine continues, "effecting the complete severance of ties between birth parents and children..."134

The closed approach also makes little sense in the context of surrogacy. The Law Commission has submitted that, as surrogacy arrangements are unenforceable and as such rely on a strong relationship to function, a personal relationship is likely to continue between the surrogate and the intending parents after the child is born. This is especially likely if the surrogate is a relative or a friend of the intending couple. ${ }^{135}$

\section{Adoption in surrogacy arrangements}

The Adoption Act is therefore highly problematic, and not an adequate mechanism through which to funnel surrogacy arrangements.

This is exacerbated by the difficulties in applying specific sections, ss 6 and 25, to surrogacy.

(a) Section 6

\footnotetext{
${ }^{126}$ Law Commission, Adoption, above n 115, at [9].

${ }^{127}$ I A M FC Wellington, FAM-2010-085-001075, 5 July 2011 at [11].

${ }^{128}$ Law Commission Adoption, above n 115, at [27]-[29].

129 At [27]; [76].

${ }^{130}$ At [28]-[29]; Legal Parenthood Discussion Paper, above n 10, at [3.5].

${ }^{131}$ Law Commission, Adoption above n 115, at [29].

${ }^{132}$ Adult Adoption Information Act 1985, ss 4, 9.

133 At [29].

134 At [29].

${ }^{135}$ Legal Parenthood Discussion Paper, above n 10, at [5.7]
} 
Section 6 provides that it is unlawful to have a child in your home with a view to adoption without prior approval of CYFS. Intending parents in surrogacy arrangements may breach this section, as there may be an expectation they begin to care of the child gestated "for them" immediately after birth. ${ }^{136}$

In at least one New Zealand case, the intending parents were not aware of the section 6 requirement of which they were in breach. CYFS accordingly opposed the adoption order. ${ }^{137}$

(b) Section 25

Although s 14 of the HART Act 2004 prohibits commercial surrogacy, altruistic surrogates may be reimbursed for reasonable medical or legal expenses incurred. This sits uncomfortably with s 25 of the Adoption Act, which prohibits payments in consideration for adoption. $^{138}$

Accordingly, to provide for the status of children born from surrogacy, the courts have been required to take an "ambulatory approach to the legislation and interpret its provisions in a modern context". ${ }^{139}$ Even where ss 6 and/or 25 have been breached, an adoption order will be granted provided the intending parents are suitable and the adoption is in the welfare and best interests of the child. ${ }^{140}$ Although breaches of these sections constitute an offence against s 27 of the Act, a court will be unlikely to take any action to punish offenders where an adoption has been approved; "as convicting the adopters would hardly seem to be in the child's best interests". 141

The approach taken by the New Zealand courts to the above sections is illustrated in the 2012 judgment Re an application to adopt a child by SCR and MCR (Re SCR). ${ }^{142}$

(c) $\operatorname{Re} S C R$

Re SCR involved a couple who had entered into a commercial surrogacy arrangement (legally) in California. While s 6 was originally complied with, the approval expired before an adoption application was filed with the Family Court. Judge Walsh considered the relevant issue to be whether the breach reflected adversely on the applicants' status as fit and proper persons. As the nature of the breach was merely "technical", it did not. ${ }^{143}$

Due to the commercial nature of the surrogacy, the intending parents also appeared to contravene s 25 of the Adoption Act, which prohibits payments in consideration of adoption.

${ }^{136}$ See Legal Parenthood Report, above n 2, at [7.25].

${ }^{137} \operatorname{Re} G$ DC INV Adopt 6/92, 3 February 1993 as cited in Legal Parenthood Report, above n 2, at [7.25]

138 Legal Parenthood Report, above n 2, at [7.26].

139 In the matter of $C$ [Adoption] [2008] NZFLR 141 at [5].

${ }^{140}$ Henaghan and Atkin, Family Law Policy, above n 41, at 282.

${ }^{141}$ Craig Rotherham "Surrogate Motherhood in New Zealand: A Survey of Existing Law and an Examination of Options for Reform" (1989-1992) 7 Otago L Rev 426 at 445.

${ }^{142}$ [2012] NZFC 5466.

${ }^{143}$ At [41]. 
Judge Walsh found that when determining whether s 25 applied, the Court must have regard to the welfare and best interests of the child. ${ }^{144}$ His Honour also considered that s 25 applied only to commercial transactions involving an element of financial profit for a surrogate parent, excluding altruistic arrangements in which the surrogate did not profit but was merely reimbursed. $^{145}$

In this case, although the arrangement involved financial profit, the Court noted that the intending couple themselves had only paid for the IVF medical fees, medical assurance and travel and accommodation. Any commercial fees paid to the surrogate were paid by the American paternal grandfather who was not a New Zealand citizen and therefore could not be subject to $\mathrm{s} 25 .{ }^{146}$ One might question whether the structuring of the payment should allow the parents to circumvent the section. Regardless, the Court considered any payment that was made to the surrogate was consideration for surrogacy and not adoption specifically. ${ }^{147}$

The above reasoning was underscored by the Court's consideration of whether the placement of the child with the parents would be the child's welfare and best interests. The Court determined a decision to refuse the application would mean the child would become liable for deportation upon the expiry of her visitor's visa, an outcome "repugnant" to her best interests. $^{148}$

(d) Analysis

The above case demonstrates the willingness of the New Zealand courts to find ways around the seemingly plain wording of ss 6 and 25 to allow intending parents to adopt children born of surrogacy.

This is particularly problematic in relation to s 25 . As argued by Craig Rotherham: ${ }^{149}$

Regardless of how unfair comparisons of surrogacy with baby selling may be, it is difficult to avoid the conclusion that, in cases where payments are made by intending parents who intend to adopt subsequently, at least part of the payment is made in consideration of the adoption.

When ECART approves an application for clinical surrogacy, it is the body's expectation that any children born as a result will be adopted in order to protect the interests of all parties involved. ${ }^{150}$ Therefore instances where thought was never given to adoption will be rare. ${ }^{151}$

There has also been scepticism that the aim of the section is to ensure the suitability of the adoptive parents as opposed to a broader section against the commodification of children. ${ }^{152}$

${ }^{144}$ Family Law Service, above n 107, at [6.701].

145 At [6.701].

${ }^{146} \operatorname{Re} S C R$, above n 148, at [57].

147 At [57].

148 At [69].

${ }^{149}$ Rotherham, above $\mathrm{n} 141$, at 438.

${ }^{150}$ In the matter of C [Adoption] [2008], above n 139, at [19].

${ }^{151}$ Rotherham, above $\mathrm{n} 141$, at 439. 
In relation to international commercial arrangements, as in $\operatorname{Re} S C R$, to argue that any payment is for the surrogacy and not the baby is "specious". ${ }^{153}$ Wilentz CJ in the landmark Baby $\mathrm{M}$ case went so far as to state that: ${ }^{154}$

It strains credulity to claim that these arrangements...really amount to anything other than a private placement adoption for money.

While New Zealand's judiciary have been using all of the tools at their disposal to interpret the law into the $21^{\text {st }}$ century, it is untenable to continue to rely on reasoning extending the provision so far beyond the statutory wording, however well-intentioned. This could be avoided by the implementation of a clear mechanism allowing the transferral of parental rights in surrogacy separate from the scheme of the Adoption Act.

(e) Effects

As a result of the numerous difficulties with adoption in surrogacy, resulting children are often cared for informally "without the protections a legal parent can provide.",

A common scenario is for the surrogate to enter her own name and the intending father's name on the birth certificate, without taking further steps in relation to the child's legal status. ${ }^{156}$ As illustrated in Re Application by $A L H$, this action may be unlawful if the surrogate has a partner deemed to be the child's legal parent.

An adoption application could proceed under the guise of a step-parent adoption, with the fact the child arose from a surrogacy arrangement not disclosed to the court. ${ }^{157}$

A surrogacy arrangement can also be hidden if the surrogate registers the names of the intending parents on the child's birth certificate, having previously registered herself with her doctor, midwife, or hospital in the name of the intending mother. While clearly unlawful, there is anecdotal evidence this has happened. ${ }^{158}$

Some parents struggle with the title of adoption and the associated connotations of having assumed parentage of a child from the "real" or biological parents. Intending parents with a genetic link may already view the child as theirs. For example, the Law Commission interviewed "Mr A", who conveyed that he had not taken any steps to secure a legal relationship with his child as he considered it "wrong that he should have to adopt his own child to become a legal father". ${ }^{159}$ This view is similar to that of the potential intending father

\footnotetext{
${ }^{152}$ Henaghan and Atkin, above n 41, at 281.

${ }^{153}$ Legal Parenthood Discussion Paper, above n 10, at [4.45].

${ }^{154}$ In re Baby $M$, above n 27, at 1241. See also Rotherham, above n 141, at 438.

${ }^{155}$ Legal Parenthood Report, above n 2, at $x x$.

${ }^{156}$ Legal Parenthood Discussion Paper, above n 10, at [4.30].

${ }^{157}$ Legal Parenthood Report, above $n$ 2, at [7.8].

158 At [7.8].

${ }^{159}$ Legal Parenthood Discussion Paper, above n 10, at [4.38].
} 
in his blog post cited earlier, who added that "[t]he very thought of having to adopt my own child, selfishly perhaps, filled me with utter revulsion.","160

In all of the above scenarios, either deception has taken place or a parent has settled for less than full legal parenthood. A lack of legal authority is concerning as "children are best supported where their social caregivers have the legal rights and responsibilities to act as effective parents." 161 Without these legal rights: parents are unable to legally consent to medical treatment on their child's behalf; enrol them in school; apply for a passport; or ensure the child is entitled to succession benefits. ${ }^{162}$

This decision also has legal consequences for the surrogate. One surrogate interviewed by the Law Commission expressed concern at the legal implications of her on-going status as the child's legal parent. ${ }^{163}$

The Law Commission's New Issues in Legal Parenthood Report concludes in regard to the Adoption Act and surrogacy: ${ }^{164}$

The current adoption model is inappropriate for surrogacy arrangements where one or both of the intending parents are genetic parents of the child; it requires screening of all applicant parents regardless of genetic affinity; it comes into effect only after the child is born; it makes it difficult for the intending parents to care for the newborn child in the two weeks post-birth; and it prohibits the passing of money between birth and adoptive parents.

\section{E International Surrogacy}

Stephen Franks MP argued in response to prohibition on commercial surrogacy included in the Human Assisted Reproductive Technology Bill that: ${ }^{165}$

New Zealanders will do it. They will go to the United States, China, or some Pacific Island country - somewhere where someone will carry a child for them - and they will pay the women handsomely.

This statement turned out to be prophetic. As only altruistic surrogacy is permitted in New Zealand, it can be difficult to find a woman to act as a surrogate, especially if the intending parents have no prior relationship with her. ${ }^{166}$ In 2011 CYFs had 63 inquiries from people looking to go overseas to engage in surrogacy as a last resort. ${ }^{167}$

\footnotetext{
160 "What about me or is that far too selfish?", above n 114.

${ }^{161}$ Claire Phillips "Case note: Reforming the laws governing parenthood" (2004) 4 BFLJ 240 at 240.

${ }^{162}$ Legal Parenthood Report, above n 2, at [7.30].

163 At [7.23].

${ }^{164}$ Legal Parenthood Report, above n 2, at [7.27].

${ }^{165}$ (6 October 2004) 620 NZPD 15917

${ }^{166}$ Jenni Millibank "The New Surrogacy Parentage Laws in Australia: Cautious Regulation or 25 Brick Walls?" (2011) 35 MULR 165 at 206.

${ }^{167}$ Shabnam Dastgheib "Rent-a-womb babies could end up stateless" (20 August 2011) Stuff.co.nz $<$ www.stuff.co.nz>
} 
A child born outside of New Zealand pursuant to a surrogacy arrangement, due to the operation of the Status of Children Act, is not eligible to claim New Zealand citizenship by descent through an intending parent. Consequently, that child generally cannot hold a New Zealand passport or reside locally until a permanent legal parent-child relationship is established through adoption. ${ }^{168}$ The child is normally brought into the country on a temporary visa whilst the adoption takes place. ${ }^{169}$

The adoption requirement is especially frustrating considering some favoured destinations of New Zealand parents engaging in surrogacy, for example California, recognise the intending parents as the legal parents. ${ }^{170}$ In September 2013, 3 News reported the story of Rees Rear and Brett Ramsey, a Kiwi couple living in Australia who conceived their three children with a surrogate in the United States. Although the men are listed on the children's birth certificates, under New Zealand law the surrogate and her partner are the legal parents. To achieve citizenship by descent for their children, they would be required to adopt. This absurdity is summed up well in Rear's words, "on their birth certificates we are the parents, so we don't know how we could possibly adopt from ourselves."171

\section{Adoption (Intercountry) Act 1997}

New Zealand is a signatory to the Hague Convention on the Protection of Children and CoOperation in Respect of Intercountry Adoption (the Hague Convention). ${ }^{172}$ The Adoption (Intercountry) Act 1997 (1997 Act) purports to implement the Hague Convention. ${ }^{173}$

The aim of the Hague Convention and 1997 Act is to establish safeguards for intercountry adoptions. ${ }^{174}$ The Hague Convention will be engaged if adoptive parents habitually resident in New Zealand seek to adopt a child habitually resident in another State party to the Convention. The child may only be adopted in New Zealand if the adoption complies with the Hague Convention. ${ }^{175}$

There was a question that if the state in which an intending party engages in international surrogacy is party to the Hague Convention, and that parent then seeks to adopt, the 1997 Act requirements could be engaged in relation to the surrogacy. Among other things, the Convention requires that consent to an adoption cannot be induced by payment or

\footnotetext{
${ }^{168}$ Department of Internal Affairs, Child Youth and Family Services, and the Department of Labour "Joint Agency Communication on International Surrogacy" Department of Internal Affairs <www.dia.govt.nz> ${ }_{169}$ Mark Henaghan "Sixth World Congress on Family Law and Children's Rights: International Surrogacy Trends: How Family Law Is Coping" (6 ${ }^{\text {th }}$ World Congress on Family Law and Childrens' Rights, Sydney, 19 March 2013) at 13. Accessible at <www.lawrights.asn.au $>$

${ }^{170}$ See Re an application by BWS to adopt a child, above $\mathrm{n} 80$.

${ }^{171}$ Morton "Couple's kids denied citizenship over surrogacy", above n 80.

${ }^{172}$ Convention of 29 May 1993 on Protection of Children and Co-operation in Respect of Intercountry Adoption (concluded 29 May 1993, entered into force 1 May 1995).

${ }^{173}$ Law Commission Adoption, above n 115, at [57]

${ }^{174}$ At [57]

175 Adoption (Intercountry) Act 1997, s 12.
} 
compensation of any kind. ${ }^{176}$ However, recent decisions evidence that the New Zealand courts have been willing to treat the "habitual residence" of a child born of surrogacy as the "habitual residence" of the intending parents. ${ }^{177}$ This is based on the intention of all parties that the child's stay in the overseas country is temporary, and for the child to travel to New Zealand permanently. ${ }^{178}$ This will only be the case where there is a genetic link between the intending parents and the resulting child. ${ }^{179}$

(a) Critique

The courts have interpreted the "habitual residence" requirement where possible to avoid the application of the Act. This could be considered to stretch the plain words of the statute by allowing a child to be deemed a "habitual resident" of a country which it was not born in and has never visited. This would not be necessary if the allocation of parentage in surrogacy was not subject to the international adoption framework, which, as with adoption in general, was not designed with surrogacy in mind. ${ }^{180}$

F Care of Children Act 2004

\section{Guardianship}

If the above difficulties with adoption pose a barrier to exercising rights and obligations in relation to a resulting child, a guardianship order under the Care of Children Act 2004 (CoCA) may be available.

Guardianship confers on the guardian responsibilities and rights necessary for the care and upbringing of the child, ${ }^{181}$ including the role of providing day-to-day care for the child, and determining or helping the child to determine questions about important matters such as residence, medical treatment, education, and religious denomination. ${ }^{182}$

Most parents will become guardians automatically upon birth, and those that do not may apply to the court to be appointed.

Applications for guardianship orders may be made by anybody. ${ }^{183}$ This is mitigated by the fact that courts have shown reluctance to appoint multiple guardians, due to the increased risk of disagreements over important facets of the child's upbringing. ${ }^{184}$

\footnotetext{
${ }^{176}$ Adoption (Intercountry) Act 1997, sch arts 4-5.

${ }^{177} \operatorname{Re}$ SCR, above $\mathrm{n} 142 ;$ Re KJB and LRB [Adoption] [2010] NZFLR 97; In re application by L [2003] NZFLR 529. See also Bill Atkin "Adoption law: the courts outflanking Parliament” (2012) NZFLR 119.

${ }^{178}$ Atkin "The courts outflanking Parliament", above n 177.

${ }^{179}$ In the matter of an application by DMW and $K W$ [2012] NZFC 2915, as cited in Family Law Service, above $\mathrm{n} 107$, at [6.715].

${ }^{180}$ See Henaghan, "Sixth World Congress", above n 169, at 19.

${ }^{181}$ Legal Parenthood Report, above n 2, [1.2]; Care of Children Act 2004, s 15-16.

${ }^{182}$ Care of Children Act 2004, s 16.

${ }^{183}$ Care of Children Act 2004, s 27(1)(a).

${ }^{184}$ Legal Parenthood Discussion Paper, above n 10, at [2.36]
} 
If an adoption does not occur in surrogacy: the intending couple or, if the intending father has been recorded on the birth certificate, the father's partner, may apply for a guardianship order. This would grant the authority to care for the child on a day to day basis.

\section{(a) Complications}

Guardianship creates a legal relationship lasting only for the duration of childhood. This differs from parenthood, which creates a "life-long link" between parent and child. ${ }^{185}$ Entitlements under intestacy, family protection, citizenship, and child support laws also flow purely from the fact of parenthood, and not guardianship. Therefore, for example, the child may miss out on benefits that would have accrued to a legal child. ${ }^{186}$

Furthermore those who parent the child on a day-to-day basis will likely see "guardianship or custody a lesser status than that of legal parenthood", ${ }^{187}$ and it could be argued that guardianship does not give the family "the sense of permanence and connectedness that facilitates bonding and attachment." 188 The sense of impermanence could be promoted by the fact guardianship orders can be revoked at any time. ${ }^{189}$

Accordingly it is submitted that any framework developed should focus on ensuring the facilitation of legal parenthood, as opposed to guardianship.

\section{Inducing Change: Key Themes}

\section{A Identity}

As discussed earlier in the paper, many adoptees subjected to closed arrangements were discovered to have a "psychological need" to know the true identity of their biological parents. ${ }^{190}$ There is evidence that children conceived with anonymous donor gametes may also suffer from genealogical confusion. ${ }^{191}$

The HART Act 2004 seeks to prevent these outcomes by providing a registry allowing donorconceived children access to information about their genetic parents.

\section{Identity and surrogacy}

In surrogacy arrangements, it is unlikely that a resulting child will have no contact with his or her surrogate mother. Surrogacy arrangements usually involve a strong relationship of trust

\footnotetext{
${ }^{185}$ Legal Parenthood Discussion Paper, above n 10, at [1.23]

${ }^{186}$ Legal Parenthood Report, above n 2, at [1.23], [3.12].

${ }^{187}$ Legal Parenthood Discussion Paper, above n 10, at [1.22]

188 At [1.23]

${ }^{189}$ At [1.23]; Care of Children Act 2004, s 29.

190 At [5.19]

${ }^{191}$ Stuart McLennan "Surrogacy and the child's right to identity" (2005) 5 NZFLJ 96 at 97; Legal Parenthood Discussion Paper, above n 10, at [5.22].
} 
between all parties, and an altruistic surrogate may be a relative or close friend. Therefore, there is likely to be a continuing personal relationship. ${ }^{192}$

However, issues surrounding knowledge of identity have the potential to be just as acute. ${ }^{193}$ If a resulting child were handed to intending parents immediately after birth, the child may not be aware of his or her origins. ${ }^{194}$

If the resulting child has been adopted, information about the gestational parent will likely be available under the Adult Adoption Information Act 1985. Where an adoption has not been carried out, the birth mother's information will remain on the birth certificate and her identity therefore known to any resulting child. There is otherwise no record from which the child might trace the surrogate mother.

Although most surrogacies appear to be open, experiences from adoptees and gamete donation shows it will be important for a child born of surrogacy to know who gestated them.

\section{Maori perspectives}

Ensuring relevant information about a surrogate mother is available accords with Maori values, as in tikanga Maori knowledge of whakapapa and turangawaewae is vital. ${ }^{195}$

Dr Lynley Anderson has highlighted that "the uptake of surrogacy by [Maori] is lower than that predicted by the proportion of Maori within the New Zealand population."196 She attributes this in part to the fact ART does not fit within the Maori world view of "[holistic] connectivity through whakapapa" which requires transparency about origins. ${ }^{197}$ By promoting transparency, more Maori may feel comfortable engaging in surrogacy. This would help ensure the needs, values and beliefs of Maori are treated with respect in accordance with principle (f) of the HART Act 2004. ${ }^{198}$

\section{$B$ Defining Parenthood}

Parenthood is often conceptualised as comprised of three components: a genetic bloodrelationship; gestation; and an intention to have a child. ${ }^{199}$ These components can now be divided, begging the question of "the relevance of genetic, gestational and rearing

\footnotetext{
${ }^{192}$ Legal Parenthood Discussion Paper, above n 10, at [5.8]

${ }^{193}$ Ministerial Committee, above n 4, at 69.

${ }^{194}$ Legal Parenthood Discussion Paper, above n 10, at [5.7].

195 Ministerial Committee, above n 4, at 70; Legal Parenthood Discussion Paper, above n 10, at [5.17]

${ }^{196}$ Anderson, "The practice of surrogacy", above n 48, at 256.

197 At 257.

${ }^{198}$ At 256

${ }^{199}$ Henaghan and Atkin, Family Law Policy, above n 41, at 288.
} 
contributions to parenthood, given that each of these contributions can be provided by different people". 200

The definition of maternity has created the most difficulties, particularly in cases of gestational surrogacy. In traditional surrogacy both genetic and gestational primacy are vested in the same woman, ${ }^{201}$ whereas in gestational surrogacy "identification and definition of the mother become matters of negotiable choice."202

There has been reluctance to divorce the title of legal mother from the process of gestation. This is reflected in New Zealand's current allocation of legal motherhood to the gestational mother if ART has been used. The bias towards gestation as indicative of motherhood is also supported by s 18 , which bestows the title of additional legal parent based upon the nature of the relationship with the gestational parent. This deference to gestation has created perverse results when applied to surrogacy arrangements. Arguably, genetics or intention may be more appropriate starting points for defining legal motherhood.

The majority of jurisprudence and commentary surrounding the relevance of contributions to parenthood originates from the United States.

Usually the discussion arises in the context of disputes between intending parents and surrogates. No such case has occurred to date in New Zealand. In the United States, no uniform approach to balancing the competing claims of parenthood has materialised. In fact, "the law often seems to be lurching unwittingly in opposite directions."203

Whether a dispute has arisen or all parties to the arrangement remain in agreement, recognising the role genetics, gestation and intention play in surrogacy arrangements provides a basis from which to formulate a coherent policy for the allocation of parenthood in surrogacy arrangements.

\section{Genetics}

(a) Intuitive fairness

In traditional surrogacy both genetics and gestation coincide. In gestational surrogacy the genetic connection will be absent. Proponents of genetic pre-eminence find that it is "intuitively appropriate to award maternity to the genetic mother [in gestational surrogacy]

200 New York State Task Force on Life and Law Assisted Reproductive Technologies: Analysis and Recommendations for Public Policy (New York 1998), as cited in Legal Parenthood Discussion Paper, above $\mathrm{n}$ 10 , at [3.38].

${ }^{201}$ Richard F Storrow "Parenthood by Pure Intention: Assisted Reproduction and the Functional Approach to Parentage" (2001-2002) 53 Hastings L J 597, at 604.

${ }^{202}$ At 610.

${ }^{203}$ David D Meyer "Parenthood in Transition - A United States Perspective" in Ingeborg Schwenzer (ed) Tensions between Legal, Biological and Social Conceptions of Parentage (Intersentia, Antwerp, 2007) 370 at 380 . 
because the desire for the genetic bond was the catalyst that led the parties to pursue surrogacy". 204

However, it cannot be assumed that the intending mother in gestational surrogacy (or the intending father's male partner) is genetically related to the child. ${ }^{205}$ Allowing genetics to determine parenthood in gestational surrogacy would have unintended consequences where the child is conceived by a intending parent and third party donor. ${ }^{206}$ It would require the primacy of the donor contrary to an abundance of law which states that a donor is not a legal parent for any purposes.

(b) Feminist critique

Feminist critiques point out that while a man solely contributes genetic material to reproduction, women may contribute by providing both genetic material and gestating the foetus. ${ }^{207}$ Approaches placing greater significance on the contribution of genetic material subjugate the exclusively female experience of pregnancy to the male-biased perspective. ${ }^{208}$

Two prominent US cases, Belsito $v$ Clark and Johnson $v$ Calvert, have been critiqued for placing too much emphasis on genetics and devaluing gestation. ${ }^{209}$ Belsito $v$ Clark referred to gestation as a "filtering system", 210 "subordinate and secondary" to genetics. ${ }^{211}$ Johnson v Calvert described the relevant gestational surrogate as a "genetic hereditary stranger", and analogised the relationship between the gestational surrogate and the child she was carrying with that of a foster parent. ${ }^{212}$

Anne Goodwin argues that such an approach fails to recognise that the gestational surrogate's role is more akin to co-procreator, than mere "temporary custody". ${ }^{213}$

(c) Identity

At first blush a genetics focused approach appears consistent with increased recognition of the importance of genetic heritage. However, Erin Hisano submits that "society can recognise

\footnotetext{
${ }^{204}$ Amy M Larkey "Redefining Motherhood: Determining Legal Maternity in Gestational Surrogacy Arrangements" (2002-2003) 51 Drake L Rev 605 at 624.

${ }^{205}$ Kirsty Horsey "Challenging presumptions: legal parenthood and surrogacy arrangements" (2010) 22 Child \& Fam L Q 449 at 459.

${ }^{206}$ Larkey, above n 204, at 625.

${ }^{207}$ Anne Goodwin "Determination of Legal Parentage in Egg Donation, Embryo Transplantation and Gestational Surrogacy Arrangements" (1992) 26 Fam LQ 275 at 284.

${ }^{208}$ At 284; Erin Y Hisano "Gestational Surrogacy Maternity Disputes: Refocusing on the Child (2011) 15 Lewis \& Clark L Rev 517 at 531.

${ }^{209}$ Belsito v Clark 644 NE Rep 2d 760 (Ohio CCP 1994); Johnson v Calvert 851 P 2d 776 (Cal 1993)

${ }^{210}$ Belsito v Clark, above n 209, at 762.

${ }^{211}$ At 767. See also Legal Parenthood Report, above n 2, at [7.50]

212 Goodwin, above n 207, at 282.

${ }^{213}$ At 283-284.
} 
and value the genetic link between a mother and child without making it the decisive factor in determining motherhood." 214

(d) Societal construct

Finally, it appears that "the importance attached to genetic ties is as socially influenced as much anything else". ${ }^{215}$ While genetic connection underlies parenthood laws in natural conception, ${ }^{216}$ it has been downplayed in favour of social parenthood in the context of gamete donation. $^{217}$ Submissions to the Law Commission showed that in fathers' groups genetics were very important, and considered to elevate a natural father's status above that of a stepparent acting as a social parent. Yet these groups also held the view that financial liability should be determined by social, not genetic, parenthood. ${ }^{218}$

Even within a surrogacy arrangement, if a gestational surrogate is carrying a child for the intending parents conceived with the intending father's sperm and a separate donor's egg, the intending couple will likely be anxious to assert legal parenthood through the father's genetic connection, while disavowing any legal right the egg donor might have in relation to the child despite her genetic connection. This highlights the subjectivity of views on this point, and the difficulty with treating genetics as the ultimate decider of parentage in surrogacy.

\section{Gestation}

(a) Foundation

New Zealand, as with most legal systems, still bases its laws concerning motherhood in the principle of mater semper certa est. ${ }^{219}$

Despite the fact "IVF [altruistic] surrogacy is at the end of the spectrum which raises fewest qualms about commercialisation, exploitation and harm to the participants, including the child", 220 the motivation for leaving parental rights and responsibilities with the surrogate until she consents to an adoption is designed to protect her relationship with the child.

This emphasis elevates the purported immutable bond formed between surrogate and child, during the "lengthy and arduous...process of gestation and childbirth". ${ }^{221}$ Gestation is considered to have emotional and physiological components which can make it difficult to

\footnotetext{
${ }^{214}$ Hisano, above n 208, at 531.

${ }^{215}$ Horsey, above n 205, at 459.

${ }^{216}$ Legal Parenthood Report, at [7.67]

${ }^{217}$ At $[2.8]$

${ }^{218}$ At [2.7]

${ }^{219}$ Ingeborg Schwenzer (ed) Tensions between Legal, Biological and Social Conceptions of Parentage (Intersentia, Antwerp, 2007) at 3.

${ }^{220}$ Ministerial Committee, above n 4, at 112.

${ }^{221}$ Radhika Rao "Hierarchies of Discrimination in Baby Making? A Response to Professor Carroll” (2013) 88 Ind L J 1217 at 1220 .
} 
adhere to the pre-conception intent of the parties. ${ }^{222}$ This may be exacerbated in traditional surrogacy, where a surrogate mother also has a genetic link to the child that she is carrying. ${ }^{223}$

Concerns have been raised that to automatically or upon dispute eliminate a gestational mother's parental rights in favour of a genetic or intentional intending parent would devalue her role as "co-procreator". 224

(b) Paternalism

Kirsty Horsey has argued that a focus on protecting the gestational mother is "based on assumptions that surrogates are vulnerable, easily exploited and somehow deserve special protection." 225 She argues that in fact most surrogates feel empowered by their act of altruism. ${ }^{226}$

A comparable argument is that the belief a woman cannot knowingly and intelligently agree to gestate and deliver a baby for another couple is reminiscent of rampant paternalism. ${ }^{227}$

This view is supported in the New Zealand context by the extensive requirements in clinical surrogacy at ECART approval stage ensuring that a surrogate is fully cognisant of the implications of the arrangement, and in particular the preference that she have already completed her own family. It may be unnecessarily paternalistic to tell a woman who has given birth before that she does not understand the impact of pregnancy.

This argument will not apply with the same force in private surrogacy arrangements, as no ethics approval is required.

(c) Impact of intention

Kirsty Horsey argues that the supposed immutable bond is merely a social construction perpetuating "existing normative constructions" of motherhood. ${ }^{228}$ If the surrogate never expects to be recognised as the parent or to raise the child she carries, bonding may not take place at all. $^{229}$

Concern that relinquishment might psychologically harm the gestational mother is largely based on studies in the context of adoption about the grief biological mothers experience. Surrogacy could be distinguished on the grounds that the decision to surrender parental rights

\footnotetext{
${ }^{222}$ Hisano, above n 208, at 538.

${ }^{223}$ Larkey, above n 204, at 610.

${ }^{224}$ Goodwin, above n 207, at 284.

${ }^{225}$ Horsey, above n 205, at 451 .

${ }^{226}$ At 451 .

${ }^{227}$ Johnson v Calvert, above n 209, at 785, as cited in Emily Gelmann "I'm Just the Oven, It's Totally Their Bun: The Power and Necessity of the Federal Government to Regulate Commercial Gestational Surrogacy Arrangements and Protect the Legal Rights of Intended Parents" (2010-2011) 32 Women's Rts L Rep 159 at 165.

${ }^{228}$ Horsey, above $\mathrm{n} 205$, at 461, 471.

${ }^{229}$ At 461; see also Hisano, above n 208, at 534.
} 
to somebody else is made prior to conception of the child as opposed to afterwards. ${ }^{230}$ Furthermore if an adoption is not carried out and parental status not conferred, as is common in the New Zealand context, it may be the on-going status of legal mother that causes the surrogate anxiety (as opposed to any doubt about handing over the resulting child). ${ }^{231}$

(d) Donor analysis

The surrogate's contributions could be conceptualised as a "donation", and therefore analogous to the parental rights (or lack thereof) of gamete donors. The surrogate donates her time, energy and bodily resources - and, in traditional surrogacy, her genetic material also. ${ }^{232}$

This position has been critiqued on the basis that the "commitment and contribution [of a surrogate] is unavoidably much greater than that [for example] of a sperm donor." ${ }^{233}$ The New Jersey Family Policy Council, in response to a judicial opinion which sought to analogise between surrogacy and gamete donation, protested that gestational mothers "carry babies for nine months, experience all the biological risks and bonds of motherhood" whereas sperm donors "once got paid to masturbate into a cup."

\section{Intentional Parenthood}

(a) "But for" test

Champions of intentional parenthood apply a "but for" test, reasoning that intending parents orchestrate the existence of the child, ${ }^{234}$ are the prime movers and "originators of the concept", ${ }^{235}$ and therefore but for their actions a child would not exist. ${ }^{236}$ Thus, the intending parents should be presumed to be a resulting child's legal parents.

This is consistent with the approach to parentage determinations in ordinary gamete donation, which allows the intent of the parties to override biological realities. Nonetheless, a "but for" test creates its own inherent fallacies. Conception could not also not have been achieved "but for" a gamete donation, or the aide of the surrogate.

The requisite intention would extend beyond conception to active involvement in the child's life. ${ }^{237}$ In the infamous Californian case Johnson v Calvert, ${ }^{238}$ the Calverts created an embryo with their genetic material to be carried by a gestational surrogate, Johnson. After the relationship deteriorated, the Court declared the intending parents the legal parents of the

\footnotetext{
${ }^{230}$ Horsey, above n 205, at 461 .

${ }^{231}$ See Legal Parenthood Report, above n 2, at [7.23].

${ }^{232}$ Horsey, above $\mathrm{n} 205$, at 469-470.

${ }^{233} R R v M H 689$ NE 2d 790 (Mass 1998) as cited in Storrow, above $\mathrm{n}$ 201, at 608.

${ }^{234}$ Hisano, above n 208, at 536.

${ }^{235}$ Goodwin, above n 207, at 287.

${ }^{236}$ Horsey, above n 205, at 457.

237 At 457.

${ }^{238}$ Johnson v Calvert, above n 209.
} 
impending child. The decision was influenced both by genetics and the original intentions of the parties: "...she who intended to bring about the birth of the child that she intended to raise as her own - is the natural mother under Californian law." ${ }^{239}$ [Emphasis added]

Johnson $v$ Calvert used intention as the deciding factor between competing genetic and gestational claims to motherhood. This approach could be lauded as according with gender neutrality, refraining from subjugating either gestation or genetics to the other. ${ }^{240}$

The flaw in this approach is that it relies on the assumption that "rational individuals do not change their minds after making decisions". ${ }^{241}$ As noted in the above sections, this fails to take into account that "the gestational carrier's physical and social relationship with the potential child dramatically changes as her pregnancy progresses and when she experiences childbirth." 242

(b) Certainty

Allowing legal parenthood to vest in the intending, intended parents without post-birth requirements would provide certainty and uniformity. ${ }^{243}$

In prominent Californian surrogacy case, In re Marriage of Buzzanca, the Court of Appeals emphasised that it is important to choose a primary family for the infant before his or her birth. $^{244}$

In the New Zealand context, identifying intent as the determinate factor - especially pre-birth - is difficult due to the legislature's policy decision not to allow the enforceability of surrogacy contracts. It was important to the legislature to allow the gestational mother room to assert any rights should she desire to, despite the parties' initial intent.

Intent doctrine could be used as a basis for a swift post-birth mechanism allocating legal parenthood to the intending parents (in accordance with the parties' intentions), provided the surrogate agrees. Nevertheless, one view tenders that we should be wary of a post-birth approach as "even where the surrogate mother is happy to hand over the child at birth, [this] approach to parenthood nevertheless demands that the child's life start with litigation, albeit amicable". 245

\section{Best interests}

(a) No single rule

\footnotetext{
239 At 782.

${ }^{240}$ Goodwin, above n 207, at 286.

${ }^{241}$ At 287.

${ }^{242}$ At 287

${ }^{243}$ Horsey, above $\mathrm{n} 205$, at 458.

${ }^{244}$ In re Marriage of Buzzanca 72 Cal Rptr 2d 280 (1998), as cited in Gelmann, above $\mathrm{n} 227$.

${ }^{245}$ Emily Jackson Regulating Reproduction: Law, Technology and Autonomy (Hart Publishing, Oxford Portland, Oregon, 2001) at 270 as cited in Horsey, above n 205 at 458.
} 
The above sections display the difficulty encountered in seeking to discern an overriding principle determinative of parenthood. Each approach encompasses its own set of flaws, and there is no clear justification for ranking one component above all others. ${ }^{246}$

This is consistent with the view of the Law Commission in the New Issues in Legal Parenthood Report (discussed in Part VII) that "no one factor can or should be taken to be solely determinative of legal parenthood. $" 247$

Erin Hisano has suggested a shift in focus from the parents to the child, to allow the best interests of the child test to inform policy surrounding the allocation of parentage and in disputes should the parties no longer agree. ${ }^{248}$ Best interests recognises that a single legal rule is insufficient to account for the variety of contexts in which surrogacy occurs. ${ }^{249}$ A broader test could incorporate analysis of genetic contribution, gestational bond, and pre-conception intent, and the ways in which these connections are relevant to the well-being of the resulting child. $^{250}$

\section{(b) Critique}

Imposing a child welfare test could risk holding the infertile party in a surrogacy agreement to a higher standard than both parents who conceive naturally and those conceiving via ordinary gamete donation. Neither fertile parents (nor gamete recipients) are required to validate their status. ${ }^{251}$

Additionally, in Johnson $v$ Calvert the Court stated that the best interests of the child test should not be used to determine the fact of a child's legal parentage, but goes to custody once parenthood has been established. ${ }^{252}$

\section{(c) Local context}

The best interests of the child approach would slot in easily to the current New Zealand family law framework, which treats the best interests of children as paramount in all child welfare decisions.

The Johnson v Calvert critique may, however, have credence. Legal parenthood in New Zealand has historically been treated as a fact, whether due to genetic reality or operation of law. Your parentage is generally not determined by who it would be in your best interests to parent you, although who provides your day to day care and has contact with you might be.

\footnotetext{
${ }^{246}$ See Hisano, above n 208, at 543-544.

${ }^{247}$ Legal Parenthood Report, above n 2, at [7.71]

${ }^{248}$ At 544.

${ }^{249}$ Larkey, above n 204, at 626.

${ }^{250}$ Hisano, above n 208, at 544.

${ }^{251}$ See Larkey, above n 204, at 626.

252 Austin Caster "Don't Split the Baby: How the US Could Avoid Uncertainty and Unnecessary Litigation and Promote Equality by Emulating the British Surrogacy Law Regime" (2010-2011) 10 Conn Pub Int LJ 477 at 510.
} 
The best interests test has been used in the transfer of parentage in adoption. This is less a recognition of an existing fact of parenthood, than a safeguard for the child when recognised parents renounce their rights and responsibilities in favour of others.

It would further be time consuming and ineffective to require the Court to undertake a comprehensive best interests analysis in every surrogacy case to determine who the legal parents should be. ${ }^{253}$ Those cases with ECART approval will already have "passed" a robust screening regime to ensure the arrangement will accord with the interests of all involved. If parties remain in agreement, further investigation seems superfluous.

A best interests approach could inform any new transferral of legal parenthood regime specific to surrogacy, if incorporating an element of intent analysis by dispensing with a comprehensive interests breakdown where the parties remain in agreement.

Professor Graeme Austin has argued that a parental status discussion should begin with presumptive weight to agreements reached between the parties, while remaining subject to the paramountcy principle. ${ }^{254} \mathrm{He}$ has submitted that this starting point would be consistent with the "practical functional focus" of other aspects of New Zealand family law. ${ }^{255}$

Building upon his view, if ECART has approved the arrangement, the child is born and the parties remain in agreement: it will be in the child's best interest to have their status formalised quickly (and without the contorted reasoning required in the application of the Adoption Act 1955).

In traditional surrogacy, where no ECART approval has been given, if there is no evidence the surrogate has been coerced by any means, and all parties remain in agreement post birth, the best interests approach could operate in the same way.

If there were a disagreement, the courts could then approach the question of legal parenthood and/or guardianship or co-parenting utilising the all-encompassing best interests analysis Hisano favours.

The above discussions and conclusion will be used to critique the following proposals for dealing with declarations of parentage in surrogacy in New Zealand.

\section{Proposals}

\section{A Law Commission: new issues in legal parenthood}

The Law Commission's New Issues in Legal Parenthood Report recommended that a Part 3 be inserted into the Status of Children Act 1969, empowering the court to make an interim

\footnotetext{
${ }^{253}$ See Legal Parenthood Report, above n 2, at [7.60].

${ }^{254}$ Graeme Austin “Editorial: The Law Commission's New Issues in Legal Parenthood Discussion Paper (2004)

4 BFLJ 259 at 259.

${ }^{255}$ At 259.
} 
pre-birth order transferring legal parenthood to the intending parents. ${ }^{256}$ This interim order would be confirmed and become final three weeks after birth in the absence of any objection filed by the surrogate. ${ }^{257}$

If no interim pre-birth order was sought, legal parenthood would vest in the surrogate (and any existing partner) in accordance with the current provisions of the Status of Children Act 1969. However, the court would remain able to transfer legal parenthood by court order anytime between three weeks and six months after the child is born. ${ }^{258}$

Requirements for an order would include the following: ${ }^{259}$

(a) That the surrogate be over 18 years old and already have a child herself;

(b) The relevant child must be the genetic child of an intending parent;

(c) Any payment made must only be for reasonable and necessary expenses;

(d) The parties must have undertaken separate and joint counselling; and

(e) The agreement must be entered into voluntarily: that is unconditional consent must have been given after independent legal advice has been sought.

If no interim pre-birth order was sought but the parties seek an order from the court post birth, the Law Commission added the additional requirement that the "making of the order is in the best interests of the child". ${ }^{260}$

In relation to genetic identity, the Law Commission considered all parents, whether involved in a private or clinical arrangement, should be required to inform the Registrar General of the identity of the surrogate mother (in addition to the donor's identifying information, if a donor was used). ${ }^{261}$

The Commission proposed mandatory participation in an education programme designed to impress upon the parties the importance of ensuring the resulting child is aware of the origins of his or her birth. ${ }^{262}$ Fertility clinics and counsellors would also be required to develop a "best practice" counselling protocol in this regard. ${ }^{263}$

1 Analysis

(a) Pre-birth order

\footnotetext{
${ }^{256}$ Legal Parenthood Report, above n 2, at 95.

${ }^{257}$ At 95.

${ }^{258}$ At 95 .

${ }^{259}$ At 95 .

${ }^{260}$ At 95.

${ }^{261}$ At 130 .

${ }^{262}$ At 121 .

${ }^{263}$ At 122 .
} 
The above approach seeks to ensure "clarity and certainty at the earliest possible time", 264 and gives effect to the intention of the relevant parties (provided this accords with the specified requirements). The Commission reasoned that "the planned nature of surrogacy... enables the law to set in place a degree of pre-conception and pre-birth certainty."

Facially, the pre-birth transfer of legal parentage may conflict with the current policy rendering surrogacy arrangements unenforceable. However, the Commission rationalised that recognition of parentage in this way was permissible "so long as...separately legislated for", ${ }^{266}$ as opposed to dictated by the terms of a private agreement. In addition, by allowing three weeks post birth in which a surrogate may assert her parental rights, the mechanism retains protection for the surrogate - a primary motivation for preventing the enforceability of surrogacy arrangements.

The requirement that the pre-birth order merely be confirmed also minimises the concern that it is undesirable to begin the child's life with litigation, "albeit amicable". ${ }^{267}$ Court involvement is kept to a minimum.

Additionally, by using the terminology parental order, the Law Commission divorces the transferral of parentage in surrogacy from adoption. The parental order has significant similarities with adoption; notably that the birth mother retains an opportunity to object to the arrangement. Nonetheless a parental order is likely to be more acceptable to intending parents. Several families interviewed by the Commission had indicated that they had avoided adoption due to a personal belief they should not have to adopt their "own" child (a process historically reserved for unwanted children, without a genetic connection to their adoptive parents).

(b) Traditional and gestational surrogacy

The proposal focuses more heavily on intention and gestation than genetics (although due to ECART requirements, in all clinical surrogacy arrangements one of the intending parents will be genetically related to the resulting child). For example, the Law Commission's proposal does not distinguish between gestational and traditional surrogacy: ${ }^{268}$

Both arrangements are entered into in society, and neither is unlawful so long as the arrangement is not commercial. In these circumstances it seems preferable to provide for both in the same way.

The additional donation of genes therefore does not provide any additional rights that would not accrue to a gestational surrogate. The right to object stems from the pregnancy itself.

\footnotetext{
264 At 6.

265 At [7.28].

${ }^{266}$ At [7.82].

${ }^{267}$ See Jackson, above n 245, at 270.

${ }^{268}$ Legal Parenthood Report, above n 2, [7.81]
} 
This approach recognises and protects the unique female contribution to reproduction. Yet, by providing an easy pre-birth order by which parenthood can be transferred from the surrogate, the Commission avoids paternalism by recognising that not all gestating mothers will experience an "immutable bond", and promoting a surrogate's agency to rationalise and bind herself to an agreement.

(c) Requirements

The requirements proposed for a parental order are consistent with those expressed in the ACART guidelines.

(d) Identity

The proposal recognises the importance of knowing one's genetic identity by requiring the registration of surrogate mothers with the Registrar General in the same manner as gamete donors. Additionally, mandatory education programmes are proposed, to enhance the likelihood parents will advise their children of the full circumstances of their birth, and the availability of information in the registry.

\section{Government response}

The then Labour Government agreed that the existing adoption process is not well suited to surrogacy arrangements. While the Government considered that "families created by surrogacy should not be disadvantaged through a lack of certainty and clarity", it committed only to giving "careful consideration to the design and legal implications.",269

No concrete government proposals were forthcoming. There was a change of Government in 2008, and the "new" National government has indicated that updating the outdated adoption and parentage laws are not a current priority. ${ }^{270}$

\section{B Care of Children (Adoption and Surrogacy Law Reform) Amendment Bill}

\section{Adoption reform}

Kevin Hague MP of the Green Party has created a Member's Bill designed to overhaul the current "archaic" adoption and surrogacy laws. ${ }^{271}$ The Bill is a "much more ambitious reform than is usually attempted through the Members' bill process". ${ }^{272}$ The Bill remains in the ballot and is yet to be drawn.

\footnotetext{
269 At [31].

270“Adoption and surrogacy law reform questions and answers" Green Party of Aotearoa New Zealand $<$ www.greens.org.nz $>$ at [10].

${ }^{271}$ Care of Children (Adoption and Surrogacy Law Reform) Amendment Bill (explanatory note) at 1.

${ }^{272}$ Green Party of Aotearoa New Zealand "Comprehensive modernisation of adoption law to enter ballot" (press release, 14 October 2012)
} 
Mr Hague seeks primarily to enact the proposals contained in the Law Commission's Adoption and Its Alternatives Report released in $2000 .^{273}$ The 2000 Report had proposed that adoptions should be dealt with under a new Care of Children Act, to consider the welfare and best interests of the child as the paramount consideration. CoCA 2004 was enacted, however adoption law was not updated concomitantly. ${ }^{274}$ Accordingly this Bill seeks to repeal the Adoption Act 1955 and provide for adoption by inserting a new Part 4 within the Care of Children regime, which deals with related issues of day-to-day care, contact and guardianship. ${ }^{275}$ The Adoption (Intercountry) Act 1997 would also be repealed, and its provisions incorporated into the new statute. ${ }^{276}$ In doing so, the Bill ensures that "all arrangements providing for the care of children in New Zealand are found in one statute and the law is unified." 277

To this end, the Bill also caters for altruistic surrogacy arrangements, both local and international, within the adoption framework. ${ }^{278}$

\section{Surrogacy provisions}

Subpart 3 of the Bill is concerned with surrogacy arrangements. "Permitted" surrogacy arrangements are those that fall within the guidelines of, and have been approved by, ECART in accordance with the HART Act 2004. Therefore, they cannot be of a commercial nature. ${ }^{279}$

However, cl 220(2) and (3) provide a comprehensive definition of "reasonable expenses incurred" for which the altruistic surrogate may be reimbursed without falling foul of the prohibition on commercial surrogacy, or the proposed offence in cl 183 of receiving payment in consideration of adoption.

Clause 222 details when adoption orders shall be made for altruistic surrogacy arrangements. Adoption orders in surrogacy will be subject to the ordinary provisions applicable to adoption in the Bill. ${ }^{280}$ However, whether or not there is a written surrogacy agreement appears to impact upon the available processes. Where a written surrogacy arrangement exists, cl 222(2) provides that the parties may agree to begin the pre-adoption assessment process prior to birth. Presumably this is desirable as it creates pre-birth certainty.

Features of this process include an assessment by a CYFS social worker as to the adoptive parents' suitability, ${ }^{281}$ and a written parenting plan discussing how the parties will approach contact and provide the child with information about the circumstances of his or her birth in

273 "Adoption and surrogacy law reform questions and answers", above n 270, at [3].

274 At [4].

${ }^{275}$ Care of Children (Adoption and Surrogacy Law Reform) Amendment Bill, cls 4, 7.

${ }^{276}$ Care of Children (Adoption and Surrogacy Law Reform) Amendment Bill (explanatory note) at 3.

277 At 2.

${ }^{278}$ At 3.

${ }^{279}$ Care of Children (Adoption and Surrogacy Law Reform) Amendment Bill, cl 220.

${ }^{280}$ Clause 222(1).

${ }^{281}$ Clause 177. 
the future. ${ }^{282}$ Some aspects of the pre-adoption process will be unable to be carried out at this stage, for example consent of the birth mother, which can only be given 28 days after birth. ${ }^{283}$ The Bill also emphasises the importance of the child's consent, ${ }^{284}$ however in an adoption giving effect to surrogacy this consent would be dispensed with due to the very young age of the child involved. ${ }^{285}$

It is not clear on the face of $\mathrm{cl} 222$ whether this pre-adoption assessment could also occur prebirth in the absence of a written agreement. It may be that the clause seeks to ensure all parents engaging in surrogacy formalise the arrangement before seeking to secure legal parenthood, by delaying the process if no written agreement is in place. This approach would be a significant departure from the current approach taken by fertility clinics to refer all prospective parents to CYFS for an assessment prior to conception, let alone birth. ${ }^{286}$

After the birth of the child, if the applicants have been accepted as suitable to adopt, pending the adoption order the commissioning parents may provide day-to-day care for the child. This is subject to the consent of the birth mother, and the approval of the social worker or the Court on application. ${ }^{287}$

(a) Analysis

There are substantial differences between the Law Commission's approach to the issue in 2005 and the approach taken eight years later in the currently proposed Bill.

(i) Framework

New Issues in Legal Parenthood had focused on changes to the Status of Children Act 1969 as opposed to CoCA. The Law Commission also sought to establish a parental order regime entirely separate from adoption, whereas the current proposed Bill seeks to provide for surrogacy within a revamped adoption framework.

Providing for surrogacy within CoCA makes sense, given that this statute otherwise governs important issues pertaining to the care of children. ${ }^{288}$

The Bill's proposers' cite the Law Commission's 2000 Adoption Report as inspiration. There is no reference to the Law Commission's 2005 comprehensive proposal for transferral of parentage in surrogacy.

${ }^{282}$ Clause 176.

${ }^{283}$ Clause 171(2)(b).

${ }^{284}$ Clause 174.

${ }^{285}$ Clause 174(2).

286 “Adopting a step or surrogate child" Child Youth and Family <www.cyf.govt.nz>

${ }^{287}$ Care of Children (Adoption and Surrogacy Law Reform) Amendment Bill, sub-cl 222(3).

${ }^{288}$ Henaghan and Atkin, Family Law Policy, above n 41, at 287. 
One potential justification for this is that a separate mechanism for the transferral of parentage in surrogacy was largely motivated by the awkward application of the Adoption Act 1955. If the 1955 legislation is repealed and adoption updated, arguably a separate mechanism is no longer required.

This is supported by the attempts in the Bill to specifically address issues of application in the 1955 Act, such as the difficult application of s 25. While retaining a prohibition on payments in consideration of adoption, the Bill makes it clear that payments of reasonable expenses incurred in an altruistic surrogacy arrangement are permissible and will not impede adoption. ${ }^{289}$ For the avoidance of doubt, the Bill contains a comprehensive list of payments which would fall under "reasonable expenses". 290

(ii) Purpose

Nonetheless, the new adoption framework does not fully accommodate the unique considerations of surrogacy. Despite recognition in the 2000 Act that adoption today has many purposes beyond providing for children whose parents cannot care for them, the principles and objects of the Bill set out in cl 165 state that: ${ }^{291}$

[a]doption is to be regarded as a service for the child in order to provide that child with permanent legal parents where that child's parents, family or whanau are not able to care for the child.

This does not encompass the motivations behind surrogacy arrangements. Additionally, this perpetuates the connotations attached to the term adoption that have prevented intending parents from formalising their roles in the past. For the average New Zealander, the term adoption will have the same implications whether contained in an Adoption or a Care of Children Act.

\section{(iii) Requirements}

Despite the provisions specific to altruistic surrogacy, intending parents are subject to the same adoption conditions as those without genetic connection who have not "orchestrated" the child's conception. Intending parents must still be assessed as to their suitability to parent. This places infertile couples at a substantial disadvantage to those who conceive genetic children without ARTs, whose suitability to parent is not assessed.

A comprehensive assessment at this stage is perhaps less appropriate where the parents have already undergone a robust investigation into the arrangement by ECART. If ECART has already approved the circumstances prior to conception, it makes little sense to impose further assessments of suitability after the fact.

\footnotetext{
${ }^{289}$ Care of Children (Adoption and Surrogacy Law Reform) Amendment Bill, sub-cl 220(2).

${ }^{290}$ Clause 220(3).

${ }^{291}$ Clause 165(b).
} 
(iv) ECART approval

Problematically, where ECART approval has not been given, it appears that no adoption order can be made under the provisions applicable to altruistic surrogacy. Sub-clause 220(1)(d) holds that for an altruistic arrangement to be permitted, the proposed arrangement must fall within the guidelines of and have been approved by ECART.

As the ECART guidelines currently govern clinical surrogacy, the above provision appears to exclude private surrogacies. As a private surrogacy would not qualify as a permitted "altruistic surrogacy arrangement" under the Bill, ostensibly the altruistic surrogacy provisions relating to adoption would not apply. It is unclear the effect this would have on private surrogacies, and whether the intending parents could simply apply for adoption in the normal fashion given that adoption in surrogacy appears to be for the most part subject to the same provisions.

It is unclear why the Bill would exclude private surrogacies from the surrogacy provisions, as provided they are altruistic, they remain legal under the HART Act 2004. If the approach was to ensure that the arrangement had been carried out ethically, this could be achieved by rephrasing the relevant sub-clause to read "falling within the guidelines of or have been approved by [ECART]". This would ensure that private surrogacies were included, and the status of children resulting from private arrangements were provided for, but also that these arrangements were carried out in accordance with recognised ethical principles.

(v) Identity

The Bill ensures that adoptions will be open unless this conflicts with the welfare and best interests of the child. This is ensured by a required written parenting plan, which sets out the parties' intentions regarding contact and proposed arrangements as to informing the child of the origins of his or her birth. ${ }^{292}$

This process is also required in surrogacy adoptions. ${ }^{293}$ While the ECART process already requires that parties undertake a discussion of this nature, the formal organisation of a written parenting plan will consolidate the approach to informing the resulting child about his or her background. Parenting plans could be particularly helpful in surrogacy arrangements which did not go through the ECART approval process.

\section{International Surrogacy}

(a) Adoption in New Zealand

\footnotetext{
${ }^{292}$ Clause 176.

${ }^{293}$ Clause 222(1).
} 
The Bill also includes a provision which dictates when an adoption could be granted in New Zealand for a child born via international surrogacy. The Bill makes it clear an adoption would only be granted if the international arrangement was altruistic in nature. ${ }^{294}$

Intending parents could apply for leave to commence a pre-adoption assessment process in a New Zealand Court in respect of a child born of altruistic surrogacy overseas. ${ }^{295}$ To do so, the parents would have to be parties to a written altruistic surrogacy arrangement; the arrangement would have to be lawful in the country where the surrogacy was to occur; and the arrangement could not be repugnant to the purposes and principles of the newly amended CoCA, HART Act 2004, or any guidelines set down by ECART or ACART. ${ }^{296}$

(b) Status of Children Act amendments

A number of proposed amendments to the Status of Children Act 1969 are also included. These would protect the status of children born via surrogacy elsewhere, if the country of birth has legally recognised the relationship between the child and the intending parents.

Section 5 would be amended to include the presumption that if a child is born in a foreign country, and parents are named on the child's birth certificate or a court order allocating parentage, this will be prima facie evidence that the named persons are the legal parents of the child in New Zealand. This appears to be the case regardless of whether that relationship would have been recognised locally under the Status of Children Act $1969 .^{297}$

(c) Analysis

This approach seeks to facilitate international surrogacies, provided that they are consistent with both the laws of New Zealand and of the country in which the surrogacy occurs. The inherent difficulty however is that, as evidenced by international surrogacy adoptions in the New Zealand courts; international surrogacies are not often altruistic. Couples may head overseas to a country in which women are willing to act as surrogates for compensation, as a result of an inability to find a willing altruistic surrogate locally.

The Bill does seek to strike a balance with the amendments to the Status of Children Act 1969. Parents that engage in commercial surrogacies overseas and have their parentage recognised in that jurisdiction would be presumed to be the legal parents in New Zealand, despite not having adopted the children.

\footnotetext{
${ }^{294}$ Clause 223.

${ }^{295}$ Clause 223(1).

${ }^{296}$ Clause 223.

${ }^{297}$ Part 2, cl 8.
} 
This would remedy the illogical situation faced by the previously mentioned Rees Rear and Brett Ramsey, who could not obtain citizenship by descent for their children without adoption despite being listed on their birth certificates as the legal parents. It could also have the effect of ensuring New Zealanders pursue commercial surrogacy only in countries willing to recognise their legal parentage. This would ensure New Zealand courts would not be forced to effectively ratify commercial arrangements inconsistent with local policy.

This hands-off approach to commercial arrangements is a significant departure from the previous position shared by most Commonwealth courts. ${ }^{298}$ The tendency has been to focus primarily on the welfare of the child, in effect ignoring normal legal requirements "in order to ensure that a child grows up in a safe and stable home and has a right to citizenship."299 This approach was evidenced in the earlier mentioned case of $\operatorname{Re} S C R$. The Court was willing to accept that the New Zealand intending parents had not made a commercial payment to the surrogate, as the element of the money beyond reimbursement was paid by the resulting child's grandfather, an American citizen.

An earlier draft of the proposed Bill contained a provision which provided that an international commercial surrogacy arrangement would not of itself prevent an adoption application from being lodged, or compel the Court to refuse to grant an order. The provision was included "to avoid doubt" that the welfare and the best interests of the child would be the paramount consideration. ${ }^{300}$

Professor Mark Henaghan has expressed disappointment that this provision was removed, and argued that any new surrogacy legislation needs to address what happens to the status of the resulting child: ${ }^{301}$

Not to recognise the parentage and/or citizenship of children born via international surrogacy is to leave these children in legal limbo and to disconnect them from their commissioning parents who seek to have, love and nurture these children.

\section{Recommendations}

The Care of Children (Adoption and Surrogacy Law Reform) Amendment Bill is yet to be drawn from the ballot, but provides the best contemporary opportunity to give the outdated law a much needed facelift. However, the author submits that the proposed Bill could benefit by incorporating elements of the 2005 recommendations.

\section{A Parental Orders}

\footnotetext{
${ }^{298}$ Henaghan, "Sixth Congress", above n 169, at 16.

${ }^{299}$ At 16.

${ }^{300}$ At 18 .

${ }^{301}$ At 21 .
} 
It is desirable to include the mechanisms for the transferral of parentage within CoCA, to ensure that all arrangements concerning the care of children are found in one piece of unified legislation. However, the amendments should distinguish between adoption and the transferral of parentage in surrogacy. The surrogacy transferral mechanism could be referred to as a "parental order".

This is in recognition of the incompatibility of surrogacy with the understood purposes of adoption. The connotations attached to adoption could prevent intending families from seeking to formalise their relationship with a resulting child.

This would also differentiate between parental transfer requiring CYFS approval (adoption), and that which does not. Provided the altruistic surrogacy arrangement otherwise meets the requirements attached to pre-birth orders, intending parents should not have to be separately assessed for their suitability to parent. If there is a genetic connection between an intending parent and the resulting child, the couple should not be subjected to assessments not required of their fertile counterparts, or other couples experiencing infertility who are able to conceive via gamete donation.

\section{B Pre-birth Orders}

In addition, the author prefers a hybrid approach to the relevant order itself. The interim prebirth order proposed in the Law Commission's 2005 Report provides greater pre-birth certainty than the mere allowance to begin pursuing adoption at an earlier stage afforded by the Bill. A pre-birth order still protects the surrogate by allowing her to assert her rights as gestational parent before the order is finalised post-birth.

The surrogacy mechanism could retain several of the requirements proposed by the Bill. For example, the requirements attached to a pre-birth order (or post-birth order granted between three weeks and six months after birth) could be updated to read that an order will be granted where the arrangement falls within the guidelines of, or has been approved by ECART, and the surrogacy is in accordance with the HART Act 2004. This incorporates both clinical and private surrogacies, and would also ensure that the surrogacy provisions only apply where there is a genetic connection between an intending parent and the child.

It is of concern that ECART approval is not currently given to same-sex or single males, and therefore that this approach could risk discrimination. For this approach to be inclusive of all prospective parents, as envisaged by the proposed Bill, the ECART guidelines must be changed in this regard.

Additionally, the issuance of a pre-birth order should be contingent upon the Court's approval of a written parenting plan, as proposed by the Bill. This is a welcome and innovative preemptive mechanism to promote open relationships and ensure the parties have considered how they wish to broach the child's circumstances of birth with the child. 
As surrogacy generally involves the use of ARTs, the author considers that the 2005 proposal that information regarding the gestational mother be recorded with the central registry, as with genetic parents, should also be retained. This would ensure that the provisions relating to surrogacy accord with not only the knowledge of identity requirements of adoption, but also gamete donation. As surrogacy may also involve third party gamete donation, it would be useful for a resulting child to be able to locate all of this information in one place.

To ensure a degree of coherence between the Bill's proposed adoption laws and surrogacy, the period in which a gestational mother may assert her rights post birth should be extended from 21 to 28 days.

\section{Disagreement}

In both proposals, legal parenthood would remain vested in the surrogate mother should she refuse to either consent to an adoption or object to the issue of a final parental order. As suggested by the Law Commission in 2005, if the agreement breaks down a court process could resolve the dispute and determine parenthood, day-to-day care and contact with the child in accordance with the child's best interests. ${ }^{302}$ This could all be undertaken under the umbrella of CoCA.

\section{International Surrogacy}

The issues surrounding international surrogacy are complex, and deserve more analysis than can be provided in this paper. ${ }^{303}$

The focus on altruistic arrangements in the Bill is understandable. It is difficult to see how a New Zealand court could grant legal parenthood in a commercial surrogacy situation without undermining New Zealand's prohibition on commercial arrangements.

The proposed amendment to the Status of Children Act 1969 strikes a tentative balance between parental recognition and local policy by letting legal parentage achieved through a commercial surrogacy arrangement lie provided the recognition of that legal parentage was provided elsewhere.

However, as pointed out by Mark Henaghan, international commercial surrogacy will continue to be prevalent. It cannot be guaranteed New Zealanders will undertake these arrangements in countries which will recognise their legal parenthood. Preventing recognition

\footnotetext{
${ }^{302}$ Legal Parenthood Report, above n 2, at $x x$.

${ }^{303}$ For recent student papers on international surrogacy, see Chantal Hickey "When children of New Zealanders have no right to citizenship: the challenges of international surrogacy and immigration law" (LLB(Hons) Dissertation, Victoria University of Wellington, 2012); and

Annika Tombleson "Contracting the New Delhi Belly: Responding to the Practice of International Surrogacy" (LLB(Hons) Dissertation, University of Otago, 2012)
} 
of these caregivers as legal parents may undermine the aim of the Bill to provide for the welfare and best interests of resulting children.

Accordingly it is suggested that the previously removed section regarding adoption in international commercial surrogacy should be reintroduced to err on the side of child welfare. If the Bill is drawn, this provision would be subject to the scrutiny of Parliament and a Select Committee process with the ability to consider the vast policy considerations engaged by the section, and balance the competing interests appropriately.

\section{Conclusion}

Surrogacy has posed unique challenges to New Zealand's outdated legal parenthood laws. The courts have "stepped into the gap that Parliament and the government, by failing to bring the law up-to-date, have left", ${ }^{304}$ in order to provide for the welfare and best interests of children resulting from surrogacy.

The Care of Children (Adoption and Surrogacy Law Reform) Amendment Bill is now poised within the ballot. This provides an opportunity for Parliamentarians to formulate a clear legal framework designed specifically for the transferral of parentage in surrogacy arrangements.

The framework recommended by this paper is predicated on giving effect to the intentions of the parties to the arrangement, while ensuring the interests of the surrogate are protected and that arrangements are carried out in accordance with recognised ethical principles. The interests of resulting children in knowing their genetic and biological backgrounds are also sharply in focus.

This approach is built on the assumption that the welfare and best interests of a child is promoted by formalising their status in relation to their intended parent as efficiently as possible. This ensures the intended parent engages with their responsibilities to the child, and the protective aspects of legal parenthood are secured.

The implications of recognition of parentage in commercial international surrogacy need to be further considered by the legislature. In any event, it should be presumed that a determination of legal parentage in the jurisdiction in which the commercial surrogacy arrangement occurred will evidence legal parentage in New Zealand law. This furthers the foundational assumptions of the proposed framework, without undermining the legislative policy of the HART Act 2004.

In summary, despite the passage of time, the conclusion to the issues engaged by legal parentage in surrogacy is the same as that reached back in 1987 regarding gamete donation:

${ }^{304}$ Atkin, "The courts outflanking Parliament, above n 177. 
"It would be wrong for Parliament to deny ... defenceless children the rights enjoyed by other children who are conceived by more orthodox or traditional means." 305

${ }^{305}$ (2 April 1987) 479 NZPD 8274. 
X Appendix 1: Relevant Statutory Provisions

\author{
A Human Assisted Reproductive Technology Act 2004
}

\title{
4 Principles
}

All persons exercising powers or performing functions under this Act must be guided by each of the following principles that is relevant to the particular power or function:

(a) the health and well-being of children born as a result of the performance of an assisted reproductive procedure or an established procedure should be an important consideration in all decisions about that procedure:

(b) the human health, safety, and dignity of present and future generations should be preserved and promoted:

(c) while all persons are affected by assisted reproductive procedures and established procedures, women, more than men, are directly and significantly affected by their application, and the health and well-being of women must be protected in the use of these procedures:

(d) no assisted reproductive procedure should be performed on an individual and no human reproductive research should be conducted on an individual unless the individual has made an informed choice and given informed consent:

(e) donor offspring should be made aware of their genetic origins and be able to access information about those origins:

(f) the needs, values, and beliefs of Māori should be considered and treated with respect:

(g) the different ethical, spiritual, and cultural perspectives in society should be considered and treated with respect.

\section{B Status of Children Act 1969}

\section{Presumptions as to parenthood}

(1) A child born to a woman during her marriage, or within 10 months after the marriage has been dissolved by death or otherwise, shall, in the absence of evidence to the contrary, be presumed to be the child of its mother and her husband, or former husband, as the case may be.

(2) Every question of fact that arises in applying subsection (1) shall be decided on a balance of probabilities.

(3) This section shall apply in respect of every child, whether born before or after the commencement of this Act, and whether born in New Zealand or not, and whether or not his father or mother has ever been domiciled in New Zealand.

17 Woman who becomes pregnant is mother even though ovum is donated by another woman

(1) This section applies to the following situation:

(a) a woman (woman A) becomes pregnant as a result of an AHR procedure:

(b) the ovum or embryo used for the procedure was produced by or derived from an ovum produced by another woman (woman B).

(2) In that situation, woman A is, for all purposes, the mother of any child of the pregnancy. 
18 When woman's non-donor partner is parent, and non-partner semen donor or ovum donor is not parent

(1) This section applies to the following situation:

(a) a partnered woman (woman A) becomes pregnant as a result of an AHR procedure:

(b) the semen (or part of the semen) used for the procedure was produced by a man who is not woman A's partner or, as the case requires, the ovum or embryo used for the procedure was produced by, or derived from an ovum produced by, a woman who is not woman A's partner:

(c) woman A has undergone the procedure with her partner's consent.

(2) In that situation, woman A's partner is, for all purposes, a parent of any child of the pregnancy.

\section{Conflicting evidence of paternity}

Sections 18, 21 and 22 have effect despite-

(a) any conflicting evidence under section 8 that the man who produced the semen was the father of the child of the pregnancy:

(b) any conflicting declaration of paternity made under section 10 that the man who produced the semen was the father of the child of the pregnancy:

(c) any other evidence that the man who produced the semen was the father of the child of the pregnancy.

C Adoption Act 1955

\section{Restrictions on placing or keeping a child in a home for adoption}

(1) It shall not be lawful for any person to place or receive or keep any child under the age of 15 years in the home of any person for the purpose of adoption, unless-

(a) prior approval has been given by a social worker, and that approval is for the time being in force; or

(b) an interim order in respect of the proposed adoption is for the time being in force.

(2) Any approval granted by a social worker for the purposes of this section shall remain in force for 1 month after it is granted:

provided that, where application to the court for an adoption order is made before the expiration of 1 month from the date of the grant of the approval, the approval shall remain in force until the application is abandoned or dismissed or an order is made by the court on the application.

(3) An interim order may be made by the court in respect of a child notwithstanding that a social worker has refused to grant an approval under this section.

(4) This section shall not apply in any case where-

(a) the child is in the home pursuant to any provision of the Children, Young Persons and Their Families Act 1989 or to an order made pursuant to that Act; or

(b) the child is in the home pursuant to an order made pursuant to the Care of Children Act 2004; or

(c) the child is in the home of one of the child's parents and a step-parent of the child; or 
(d) the child is in the home of a relative of the child (not being a relative who, in the absence of special circumstances, is prohibited, by reason of age or sex, from adopting the child).

\section{Restrictions on making of orders in respect of adoption}

Before making any interim order or adoption order in respect of any child, the court shall be satisfied-

(a) that every person who is applying for the order is a fit and proper person to have the role of providing day-to-day care for the child and of sufficient ability to bring up, maintain, and educate the child; and

(b) that the welfare and interests of the child will be promoted by the adoption, due consideration being for this purpose given to the wishes of the child, having regard to the age and understanding of the child; and

(c) that any condition imposed by any parent or guardian of the child with respect to the religious denomination and practice of the applicants or any applicant or as to the religious denomination in which the applicants or applicant intend to bring up the child is being complied with.

\section{Prohibition of payments in consideration of adoption}

(1) Except with the consent of the court, it shall not be lawful for any person to give or receive or agree to give or receive any payment or reward in consideration of the adoption or proposed adoption of a child or in consideration of the making of arrangements for an adoption or proposed adoption:

(1A) Subsection (1) does not apply to the payment of the hospital and medical expenses of the confinement of the mother of a child if-

(a) the expenses are incurred by virtue of the provision by a society or body of persons of hospital care (within the meaning of the Health and Disability Services (Safety) Act 2001) and

(b) the payment is made by an applicant for an adoption order in respect of the child directly to the society or body; and

(c) the amount paid has been approved in the particular instance, or is in accordance with a scale approved generally, by the chief executive of the department of State responsible for the administration of the Health and Disability Services (Safety) Act 2001.

(2) Subsection (1) does not apply to the payment of reasonable costs and expenses to any organisation approved as a New Zealand accredited body under Part 2 of the Adoption (Intercountry) Act 1997, provided those costs and expenses-

(a) are in connection with the exercise of a function delegated to that body under Part 1 of that Act; and

(b) are set out in an invoice or statement of account rendered by that body which sets out details of the costs and expenses, and the services or functions to which they apply. 


\section{Bibliography}

\section{A Cases}

1 New Zealand

I A M FC Wellington, FAM-2010-085-001075, 5 July 2011

In re application by $L$ [2003] NZFLR 529

In the matter of an application by DMW and KW [2012] NZFC 2915

In the Matter of C [Adoption] [2008] NZFLR 141

Keelan v Peach [2003] 1 NZLR 589

$P$ v K [2003] 2 NZLR 787

Re Adoption of H FC Wanganui FAM-2004-034-17, 13 August 2003

Re an application by BWS to adopt a child [2011] NZFLR 621

Re an application to adopt a child by SCR and MCR [2012] NZFC 5466

Re Application by ALH FC North Shore FAM-2011-044-371, 11 August 2011

Re KJB and LRB [Adoption] [2010] NZFLR 97

$\operatorname{Re} G$ DC INV Adopt 6/92, 3 February 1993

Re MSK [2013] NZFC 2064

Re P (adoption: surrogacy) [1990] NZFLR 385

Re TTK [2013] NZFC 2989

\section{Australia}

Re Evelyn (1998) 145 FLR 90

3 United Kingdom

Re an adoption application (surrogacy) [1987] 2 All ER 826

The Ampthill Peerage [1977] AC 547 (HL)

4 United States

$A H W v G H B 772$ A 2d 948 (NJ Super Ch 2000)

Belsito v Clark 644 NE Rep 2d 760 (Ohio CCP 1994)

In re Baby $M 537$ A 2d 1227 (NJ 1988)

In re Marriage of Buzzanca 72 Cal Rptr 2d 280 (1998)

In re Parentage of a Child by TJS and ALS No. FA-04-0273-09-S (NJ Super Ct Ch Div 2010)

In the Matter of Parentage of a Child By T.J.S and A.L.S 16 A 3d 386 (NJ Ap Div 2011)

In the Matter of Parentage of a Child by T.J.S and A.L.S 54 A 3d 263 (NJ 2012)

Johnson v Calvert 851 P 2d 776 (Cal 1993)

$R R v M H 689$ NE 2d 790 (Mass 1998) 


\section{B Legislation}

1 New Zealand

A Statutes

Administration Act 1969

Adoption Act 1955

Adoption (Intercountry) Act 1997

Adult Adoption Information Act 1985

Care of Children Act 2004

Children, Young Persons and Their Families Act 1989

Child Support Act 1991

Citizenship Act 1977

Family Protection Act 1955

Human Assisted Reproductive Technology Act 2004

Marriage (Definition of Marriage) Amendment Act 2013

Status of Children Act 1969

Status of Children Amendment Act 1987

Status of Children Amendment Act 2004

B Bills

Assisted Human Reproduction Bill 1998 (227-1)

Care of Children (Adoption and Surrogacy Law Reform) Amendment Bill

Human Assisted Reproductive Technology Bill 1996 (2005 195-2)

\section{Treaties}

Convention of 29 May 1993 on Protection of Children and Co-operation in Respect of Intercountry Adoption (concluded 29 May 1993, entered into force 1 May 1995)

United Nations Convention on the Rights of the Child 1577 UNTS 3 (opened for signature 20 November 1989, entered into force 2 September 1990)

\section{Books and Chapters in Books}

Cusine, Douglas "Legal issues in human reproduction" in Sheila A.M. McLean (ed) Legal Issues in Human Reproduction (Dartmouth Publishing Company Limited, England, 1989) 17 Freeman, Michael "Is surrogacy exploitative?" in Sheila A.M. McLean (ed) Legal Issues in Human Reproduction (Dartmouth Publishing Company Limited, England, 1989) 164

Henaghan, Mark and Atkin, Bill Family Law Policy in New Zealand $\left(4^{\text {th }}\right.$ ed, Lexis Nexis, Wellington, 2013) 
Inglis, BD New Zealand Family Law in the $21^{\text {st }}$ Century (Brookers, Wellington, 2007)

Kirby, Michael "Medical technology and new frontiers of family law" in Sheila A. M. McLean (ed) Legal Issues in Human Reproduction (Dartmouth Publishing Company Limited, England, 1989) 3

Jackson, Emily Regulating Reproduction: Law, Technology and Autonomy (Hart Publishing, Oxford -Portland, Oregon, 2001)

Meyer, David D "Parenthood in Transition - A United States Perspective" in Ingeborg Schwenzer (ed) Tensions between Legal, Biological and Social Conceptions of Parentage (Intersentia, Antwerp, 2007) 370

Welstead, Mary "This Child is My Child; This Child is Your Child; This Child was Made For You and Me - Surrogacy in England and Wales" in Bill Atkin (ed) The International Survey of Family Law 2011 Edition (Jordan Publishing Limited, Bristol, 2011) 165

\section{E Journal Articles}

Anderson, Dr Lynley and Mark Henaghan "Surrogacy and s2(a)(ii): Interpreting the "medical condition" requirement in ACART's Guidelines on Surrogacy Arrangements involving Providers of Fertility Services: How "Medical" is "Medical"?: The ethical and legal implications of the "medical condition" requirement in an intending mother's application of surrogacy" (2012) 7 NZFLJ 130

Anderson, Dr Lynley, Jeanne Snelling and Huia Tomlins-Jahnke "The practice of surrogacy in New Zealand" (2012) 52 Aust N Z J Obstet Gynaecol 253

Atkin, Bill "Adoption law: the courts outflanking Parliament” (2012) NZFLR 119

Atkin, Bill "Regulation of Assisted Human Reproduction: The Recent New Zealand Model in Comparison with Other Systems" (2005) 11 RJP/NZACL Yearbook 81

Atlas, Bianka "Assisted Reproductive Technology: Proposals for Reform from a Child Welfare Perspective" (2005) 5 NZFLJ 3

Austin, Graeme "Editorial: The Law Commission's New Issues in Legal Parenthood Discussion Paper" (2004) 4 BFLJ 259

Caldwell, John "In the matter of applications by BWS and ADMS to adopt a child" (2011) NZLJ 171

Carroll, Andrea B "Discrimination in Baby Making: The Unconstitutional Treatment of Prospective Parents Through Surrogacy" (2013) 88 Ind L J 1187

Caster, Austin "Don't Split the Baby: How the US Could Avoid Uncertainty and Unnecessary Litigation and Promote Equality by Emulating the British Surrogacy Law Regime" (2010-2011) 10 Conn Pub Int LJ 477

De Vito, Amanda E "Comment: Establishing and Rebutting Maternity: Why Women are at a Loss Despite the Advent of Genetic Testing” (2010/2011) 74 Alb L Rev 1873

Fisher, Dr Richard "When biotechnology and law collide: assisted human reproduction and family law: Part 1: the medical perspective" (2003) 4 BFLJ 139 
Gelmann, Emily “I'm Just the Oven, It's Totally Their Bun: The Power and Necessity of the Federal Government to Regulate Commercial Gestational Surrogacy Arrangements and Protect the Legal Rights of Intended Parents" (2010-2011) 32 Women's Rts L Rep 159

Goodwin, Anne "Determination of Legal Parentage in Egg Donation, Embryo Transplantation and Gestational Surrogacy Arrangements" (1992) 26 Family LQ 275

Guglietta, Pasquale "Baby M: An Unrequited Invitation" (2010-2011) 8 Rutgers JL \& Pub Pol'y 876

Henaghan, Mark "Editorial: Adoption - time for changes" (2006) 5 NZFLJ 131

Hisano, Erin Y "Gestational Surrogacy Maternity Disputes: Refocusing on the Child (2011) 15 Lewis \& Clark L Rev 517

Hofman, Darra L "Mama's Baby, Daddy's Maybe: a State-by-State Survey of Surrogacy Laws and Their Disparate Gender Impact” (2009) 35 Wm Mitchell L Rev 449

Horsey, Kirsty "Challenging presumptions: legal parenthood and surrogacy arrangements" (2010) 22 Child \& Fam L Q 449

Larkey, Amy M "Redefining Motherhood: Determining Legal Maternity in Gestational Surrogacy Arrangements" (2002-2003) 51 Drake L Rev 605

McLennan, Stuart "Surrogacy and the child's right to identity" (2005) 5 NZFLJ 96

Millibank, Jenni "The New Surrogacy Parentage Laws in Australia: Cautious Regulation or 25 Brick Walls?" (2011) 35 MULR 165

Phillips, Claire "Case note: Reforming the laws governing parenthood" (2004) 4 BFLJ 240

Rao, Radhika "Hierarchies of Discrimination in Baby Making? A Response to Professor Carroll” (2013) 88 Ind L J 1217

Rotherham, Craig "Surrogate Motherhood in New Zealand: A Survey of Existing Law and an Examination of Options for Reform" (1989-1992) 7 Otago L Rev 426

Salmon, David "In response to a freeman: surrogate motherhood and the feminist perspective" (1995) 1 BFLJ 276

Storrow, Richard F "Parenthood by Pure Intention: Assisted Reproduction and the Functional Approach to Parentage" (2001-2002) 53 Hastings L J 597

\section{F Parliamentary and Government Materials}

1 Hansard

(2 April 1987) 479 NZPD 8269

(30 June 1987) 482 NZPD 10104

(23 April 1997) 559 NZPD 1226

(17 November 1998) 573 NZPD 13227

(6 October 2004) 620 NZPD 15899

\section{Law Commission}


Law Commission Adoption and Its Alternatives: A Different Approach and a New Framework (NZLC R65, 2004)

Law Commission New Issues in Legal Parenthood: A discussion paper (NZLC PP54, 2004)

Law Commission New Issues in Legal Parenthood (NZLC R88, 2005)

\section{Select Committee reports}

Human Assisted Reproductive Technology Bill (2004) (195-2) (select committee report)

\section{G Reports}

Government Response to Law Commission Report on New Issues in Legal Parenthood (Ministry of Justice, March 2006)

Law Reform Division A summary of submissions received on the issues paper (Department of Justice, December 1986)

Ministerial Committee on Assisted Reproductive Technologies Assisted Human Reproduction: Navigating our Future (Reporting to Minister of Justice, July 1994)

New York State Task Force on Life and Law Assisted Reproductive Technologies: Analysis and Recommendations for Public Policy (New York 1998)

\section{H Dissertations}

Hertwig, Daniela “Surrogacy” (LLM Dissertation, Victoria University of Wellington, 2012) Hickey, Chantal "When children of New Zealanders have no right to citizenship: the challenges of international surrogacy and immigration law" (LLB(Hons) Dissertation, Victoria University of Wellington, 2012)

Tombleson, Annika "Contracting the New Delhi Belly: Responding to the Practice of International Surrogacy” (LLB(Hons) Dissertation, University of Otago, 2012)

\section{Internet Resources}

Booker, Jarrod "Surrogates: Delivering the ultimate gift" New Zealand Herald (online ed, New Zealand, 28 April 2012)

Trevett, Claire "MP seeks big adoption changes" The New Zealand Herald (online ed, New Zealand, 15 October 2012)

Dastgheib, Shabnam "Rent-a-womb babies could end up stateless" (20 August 2011) Stuff.co.nz <www.stuff.co.nz $>$

Department of Internal Affairs, Child Youth and Family Services, and the Department of Labour "Joint Agency Communication on International Surrogacy" Department of Internal Affairs $<$ www.dia.govt.nz $>$

Dunbar, Debbie "Surrogacy for same sex male couples" (21 March 2013) Rainey Collins Lawyers $<$ www.raineycollins.co.nz $>$ 
Donaldson, Susan "Test Tube Baby Louise Brown Turns 35" (25 July 2013) ABC News $<$ www.abcnews.go.com>

Farrar, David “Adoption law reform” (14 October 2012) Kiwiblog <www.kiwiblog.co.nz>

Greenfield, Beth "What are a surrogate's rights? Woman's controversial pregnancy in spotlight” (6 March 2013) Yahoo! Lifestyle New Zealand < nz.lifestyle.yahoo.com>

Morton, Rachel "Couple's kids denied citizenship over surrogacy" (15 September 2013) 3 News $<$ www.3news.co.nz $>$

"ACART: Advisory Committee on Assisted Reproductive Technology" ACART $<$ acart.health.govt.nz>

"Adopting a step or surrogate child" Child Youth and Family $<$ www.cyf.govt.nz $>$

"Adoption and Surrogacy" Jeremy Sutton Barrister <www.jeremysutton.co.nz $>$

"Adoption and surrogacy law reform questions and answers" Green Party of Aotearoa New Zealand $<$ www.greens.org.nz $>$

"ECART: Ethics Committee on Assisted Reproductive Technology" ECART $<$ ecart.health.govt.nz>

"India tightens surrogacy laws" (19 January 2013) MSN News < news.msn.co.nz>

"International Surrogacy" (19 August 2013) Safe Travel <www.safetravel.govt.nz>

"NJ Parentage Act Upheld" (2012) New Jersey Family Policy Council <www.njfoc.org>

"Surrogacy" Fertility Associates <www.fertilityassociates.co.nz>

"What about me or is that far too selfish?" (27 May 2010) How Green is My Grass?

$<$ www.djpnz.com>

\section{J Other Resources}

Advisory Committee on Assisted Reproductive Technology: Annual Report 2011/2012 (ACART, November 2012)

ACART Guidelines on Surrogacy Arrangements involving Providers of Fertility Services (Guidelines issued to ECART under section 35 of the Human Assisted Reproductive Technology Act 2004, November 2008)

Ethics Committee on Assisted Reproductive Technology: Minutes of the $35^{\text {th }}$ Meeting of the Ethics Committee on ART (ECART, 24 November 2011)

Family Law Service (online looseleaf ed, Lexis Nexis)

Green Party of Aotearoa New Zealand "Comprehensive modernisation of adoption law to enter ballot" (press release, 14 October 2012)

Henaghan, Mark "Sixth World Congress on Family Law and Children's Rights: International Surrogacy Trends: How Family Law Is Coping" $\left(6^{\text {th }}\right.$ World Congress on Family Law and Childrens' Rights, Sydney, 19 March 2013) at 13. Accessible at <www.lawrights.asn.au> Human Rights Commission "Submission of the Human Rights Commission to the Ministerial Committee on Assisted Reproductive Technologies" (April 1994) 